\title{
Identification of international opportunities: A study of mature firms in mature industries
}

\author{
Nataliya Galan ${ }^{1}$ (D) Ellinor Torsein ${ }^{1}$
}

Published online: 20 June 2020

(C) The Author(s) 2020

\begin{abstract}
This study seeks to gain a better understanding of how small late internationalising (mature) firms operating in mature industry contexts, which seem largely ignored in international entrepreneurship research, identify primary and subsequent international opportunities. Integrating international opportunity and network literature, as well as adopting a multiple case study design, we build on the evidence obtained from two Swedish and two Norwegian late internationalising firms operating in mediumtechnology industries. Our findings highlight the vital importance of business ties for identification of both primary and subsequent international opportunities by mature firms operating in mature industries. We find that such firms may identify their primary international opportunities by both discovery and creation. Furthermore, the firms' reputation in the domestic market, accumulated technological knowledge and needs for product customisation and/or customer involvement in product development, may indicate whether the firms tend to discover primary international opportunities or create them either by strengthening existing business ties or by forming new ones. With regard to subsequent international opportunities, creation is found to be a more likely way to identify opportunities. We show that 'false' (identified but not pursued) international opportunities, apart from generating a beneficial learning experience for both entrepreneurs and firms, prompt the entrepreneurs to (i) realise the urgency of needed strategic changes and (ii) identify future learning content, i.e. knowledge which should be acquired by the firm for successful pursuit of subsequent international opportunities.
\end{abstract}

Nataliya Galan

nataliya.galan@hv.se

Ellinor Torsein

ellinor.torsein@hv.se

1 School of Business, Economics and IT, University West, Trollhättan, Sweden, University West, 46181 Trollhättan, Sweden 


\section{Résumé}

Cette étude cherche à mieux comprendre comment les petites entreprises qui s'internationalisent tardivement dans des contextes industriels matures, qui semblent largement ignorés dans la recherche internationale sur l'entreprenariat, identifient les opportunités internationales primaires et ultérieures. En intégrant la littérature internationale sur les opportunités et les réseaux, ainsi qu'en adoptant un modèle d'étude de cas multiples, nous nous appuyons sur les données obtenues auprès de deux entreprises suédoises et de deux entreprises norvégiennes qui s'internationalisent tardivement dans les industries de moyenne technologie. Nos conclusions soulignent l'importance vitale des relations d'affaires pour l'identification des opportunités d'affaires internationales primaires et ultérieures par les entreprises matures œuvrant dans des industries matures. Nous constatons que ces entreprises peuvent identifier leurs principales opportunités internationales à la fois par la découverte et la création. En outre, la réputation de l'entreprise sur le marché intérieur, les connaissances technologiques accumulées et les besoins en matière de personnalisation des produits et/ou la participation des clients au développement des produits peuvent indiquer si l'entreprise a tendance à découvrir les opportunités internationales primaires ou à les créer, soit en renforçant les liens commerciaux existants, soit en en créant de nouveaux. En ce qui concerne les opportunités internationales ultérieures, la création est. considérée comme un moyen plus probable d'identifier les opportunités. Cette étude montre que les opportunités internationales "fausses" (identifiées mais non exploitées), en plus de générer une expérience d'apprentissage bénéfique pour les entrepreneurs et les entreprises, incitent les entrepreneurs à (i) reconnaître l'urgence des changements stratégiques nécessaires et à (ii) identifier le futur contenu d'apprentissage, c'est-à-dire les connaissances que l'entreprise devrait acquérir pour saisir avec succès les opportunités internationales ultérieures.

Keywords International entrepreneurship $\cdot$ International opportunity identification $\cdot$ Late internationalising firms $\cdot$ Mature firms $\cdot$ Mature industries $\cdot$ Networks

JEL classifications L26 $\cdot$ L14

Mots clés Entrepreneuriat international · Identification d'opportunités internationales . Entreprises internationales de dernière minute · Entreprises matures · Industries matures · Réseaux

\section{Summary highlights}

Contributions: Our study adds to the growing body of knowledge on the importance of networks in identification of both primary and subsequent international opportunities by small late internationalising firms operating in mature industries. Specifically, using network characteristics (type, strength, locality and development of ties), we provide insights to variations in international opportunity identification by these firms, thus contributing to theoretical advances in international opportunities. 
Purpose/Research questions: Our study aims at advancing knowledge on the preamble phase of firms' internationalisation: international opportunity identification. Responding to calls for extending international entrepreneurship research to mature industry contexts, focusing on late internationalising firms and embracing the network approach, we seek to gain a better understanding of how mature small firms operating in mature industries identify their (i) primary and (ii) subsequent international opportunities.

Methods, data and sample: We adopt a qualitative research strategy and a multiple case study design. The study is built on the evidence obtained from two Swedish and two Norwegian late internationalising firms operating in medium-technology industries. Data were mainly collected via face-to-face, semi-structured, in-depth interviews with owner-managers and founder-managers of the four focal firms.

Findings: Business ties appear to be of vital importance for identification of both primary and subsequent international opportunities by mature firms operating in mature industries. Although such firms may identify their primary international opportunities by both discovery and creation, the firms' reputation in the domestic market, accumulated technological knowledge and needs for product customisation and/or customer involvement in product development, may indicate whether the firms tend to discover primary international opportunities or create them either by strengthening existing business ties or by forming new ones. Subsequent international opportunities are found to be more likely created than discovered. 'False' (identified but not pursued) international opportunities seem to generate a beneficial learning experience for both entrepreneurs and firms, as well as prompt the entrepreneurs to realise the urgency of needed strategic changes and identify future learning content, i.e. knowledge which should be acquired by the firm for successful pursuit of subsequent international opportunities.

Limitations and future research directions: The multiple case study design, implying a rigorous investigation of a small sample of cases, constrains the generalisation of findings. Therefore, it would be of interest to formulate hypotheses based on our findings and test them on a larger sample of small firms, preferably from a broader range of mature industries and various national contexts. Further, data obtained via interviews rely on the ability of the interviewees to memorise past life events and experiences. Hence, future research should focus on mature firms which start to internationalise relatively earlier (6 to 10 years after inception), or/and adopt longitudinal approaches.

Theoretical implications: We contribute to international entrepreneurship literature by providing novel insights into identification of international opportunities by small late internationalising firms operating in mature industries via various types of networks.

Practical implications: Based on the obtained findings, managers of small mature firms operating in mature industries and having ambitions to expand internationally are advised to develop their business networks either by creating new relationships (seems to be relevant for firms offering products, which require high level of customisation and/or customer involvement) or by strengthening existing relationships with their business partners (otherwise). 
Policy implications: Export support programs aimed at small mature firms in mature industries should provide financial and non-financial assistance to these firms to facilitate their business networking both locally and internationally.

\section{Introduction}

Over the last two decades, international opportunity has emerged as a critical concept in international entrepreneurship research (Zahra et al. 2005; Johanson and Vahlne 2006; Mainela et al. 2014), which is now broadly defined as 'the cognitive and behavioural processes associated with the creation and exchange of value through the identification and exploitation of opportunities that cross national borders' (Peiris et al. 2012, p. 296). The lens of the opportunity-based view has been employed in international entrepreneurship research to understand the processes of firms' internationalisation, which is paralleled to at least two phases - international opportunity identification and international opportunity exploitation (Chandra et al. 2009; Peiris et al. 2012; Oyson and Whittaker 2015). Growing research in the field of international entrepreneurship emphasises the importance of the first phase in a firm's internationalisation process: international opportunity identification (Chandra et al. 2009; Muzychenko and Liesch 2015), which is viewed as a precursor to a firm's commitment to international market entry (Muzychenko and Liesch 2015), and is therefore considered a trigger of the firm's international expansion (Chandra et al. 2009; Hilmersson and Papaioannou 2015).

With regard to international opportunity identification, international entrepreneurship research builds on two perspectives: opportunity discovery and opportunity creation (Mainela et al. 2014; Chetty et al. 2018). While the opportunity discovery perspective emphasises serendipity and reactive attitudes and behaviours of entrepreneurs and managers (Mainela et al. 2014), the opportunity creation perspective highlights intentionality and proactive attitudes and behaviours (Mainela et al. 2014).

The extant international entrepreneurship literature offers divergent views on international opportunity identification (Mainela et al. 2014; Chetty et al. 2018), with valuable insights on the antecedents of this process, such as a firm's prior international experience and knowledge (Chandra et al. 2009; Schweizer et al. 2010; Laperrière and Spence 2015), entrepreneurial orientation (Ripollés-Mélia et al. 2007; Chandra et al. 2009), and networks (Chandra et al. 2009; Ellis 2011; Kontinen and Ojala 2011a; Galkina and Chetty 2015). However, most of the findings have been obtained for international new ventures and 'born global' firms (Kontinen and Ojala 2011b; Reuber et al. 2017). While the international entrepreneurship field is no longer limited to researching the behaviour of international new ventures (Peiris et al. 2012), a few studies in the field have focused on other types of firms, namely those that do not aim to internationalise early and/or rapidly from their inception (Kontinen and Ojala 2011b, Reuber et al. 2017). Such firms can be defined as mature or traditional firms (Masiello and Izzo 2019) and are also labelled as non-born-globals, late internationals (Jones et al. 2011), mature exporters, enduring globals (Peiris et al. 2012) and late starters (Francioni et al. 2017). With regard to the process of international opportunity identification, it is considered to be of interest to link this process to firm type (Jones et al. 2011), thus extending the 'earliness' bounds of international entrepreneurship research (Reuber et al. 2017). 
Furthermore, international entrepreneurship research appears to have favoured studies of firms operating in high-technology and knowledge-intensive sectors (Coviello and Jones 2004; Jones et al. 2011; Peiris et al. 2012). While it is argued that a specific industry context is crucial for understanding a firm's international behaviour (Andersson 2004; Fernhaber et al. 2007; Laurell et al. 2013), which might differ in new, growing and mature industries (Andersson 2004), mature industries, characterised by lower knowledge intensity, still remain a largely understudied context in international entrepreneurship (Evers 2010, 2011; Kontinen and Ojala 2011b; Reuber et al. 2017). Recently, there have been suggestions to diversify the domain of international entrepreneurship research into different industrial contexts, especially to established industry sectors, i.e. low- and medium-technology industries (Peiris et al. 2012; Reuber et al. 2017; Stoian et al. 2017).

In addition, international entrepreneurship research appears to suffer from the 'single opportunity bias' as it overlooks historical dynamics of international development, i.e. how one opportunity may lead to others (Chandra et al. 2015). However, having identified and exploited its primary international opportunity, a firm acquires experiential knowledge on the internationalisation process, which it lacked in the beginning (Chandra et al. 2009). This means that the outcomes of the identification of one opportunity may become the antecedents of the identification and pursuit of subsequent opportunities (Reuber et al. 2017). Accordingly, the international opportunity identification process might differ considerably with regard to primary and subsequent international opportunities (Oyson and Whittaker 2015).

Responding to calls for extending international entrepreneurship research to mature industry contexts and focusing on late internationalising firms, as well as addressing the abovementioned developments in the international entrepreneurship field, we see the opportunity to further advance knowledge on the preamble phase of firms' internationalisation: international opportunity identification. Since international entrepreneurship scholars acknowledge the central role of a mixture of various ties in which firms are embedded for their internationalisation and consider the network approach to be a useful theoretical lens to study firms' international opportunity identification (Johanson and Vahlne 2009; Evers and O'Gorman 2011; Kontinen and Ojala 2011a, b; Galkina and Chetty 2015; Bai and Johanson 2018; Leppäaho et al. 2018), we embrace the network approach to seek to answer the following research question:

How do mature small firms operating in mature industries identify (i) primary and (ii) subsequent international opportunities?

We believe that the development of knowledge in this area is of importance for both theory of international entrepreneurship and practice. Small firms make diverse contributions to economic and social well-being in the advanced economies (OECD 2018). While the majority of such firms, operating in low- and medium-technology sectors, are largely embedded in local production systems and do not expand internationally, there is a cohort among those that seems to be better equipped for expanding internationally than their counterparts (OECD 2018). A better understanding of processes of international opportunity identification by such firms has a potential to enrich the field of international entrepreneurship as well as generate important implications for managers and policy-makers.

The remainder of our article is organised as follows. In the next section, we present the conceptual foundations of our study. The following section outlines the methodological approach and accounts for our strategy for data collection and data analysis. The subsequent sections present and discuss our findings, highlighting their implications for 
international entrepreneurship research, managerial practice and policy, delineating the limitations of the study, and suggesting directions for future research.

\section{Underpinning literature}

\section{International opportunity and international opportunity identification}

International opportunity is one of the most fundamental and discussed concepts in international entrepreneurship research (Mainela et al. 2014). This ongoing debate predominantly revolves around alternative definitions (Reuber et al. 2018), the origin and the ways in which international opportunities can be identified (Mainela et al. 2014; Oyson and Whittaker 2015).

Regardless of the acknowledged relevance, centrality and growing significance of the international opportunity concept for international entrepreneurship research, there is no single approach to defining international opportunities (Muzychenko and Liesch 2015; Reuber et al. 2018). According to Reuber et al. (2018), it is most common to rely on the exchange-based approach and conceptualise international opportunity as a market opportunity, in particular, as an exchange in a new foreign market. Whereas some definitions accentuate accomplished market exchanges (Mainela et al. 2014), others also take into account a potential to conduct market exchanges (Ellis 2011; Hilmersson and Papaioannou 2015; Muzychenko and Liesch 2015). In our interpretation, defining international opportunity as a 'chance' (Ellis 2011, p. 101), 'likelihood' (Muzychenko and Liesch 2015, p. 705) or 'prospect' (Hilmersson and Papaioannou 2015, p. 192) to conduct an exchange in a new foreign market implies a possibility that such an exchange will never be accomplished. Thus, a firm may identify a 'false' international opportunity, which is parallel with a failure to enter a foreign market (Chandra et al. 2012). Our study focuses on late internationalising firms, which can be disadvantaged in the process of their internationalisation (Francioni et al. 2017); as their target markets are saturated (Johanson and Mattsson 1988), their experienced competitors have more foreign market knowledge, or it is hard for newcomers to enter existing networks (Chetty and Blankenburg-Holm 2000). Thus, such firms can be more predisposed to identification of 'false' international opportunities. Therefore, for the purpose of this study, we adopt Muzychenko and Liesch's (2015, p. 705) definition of international opportunity as 'the likelihood of conducting exchange with new or existing partners, such as foreign intermediaries or foreign customers, in new international markets'.

Firms can identify international opportunities through the processes of discovery, creation or a combination of both (Muzychenko and Liesch 2015; Chetty et al. 2018). The opportunity discovery perspective, which is rooted in the Kirznerian approach to entrepreneurial opportunities (Kirzner 1997), views opportunities as objective phenomena, which exist independently of entrepreneurs, and are 'just waiting to be discovered' (Zara et al. 2005; Alvarez and Barney 2007). The discovery of opportunities is seen as a reactive process (Kontinen and Ojala 2011a) and a result of alertness of entrepreneurs who possess particular capabilities, such as rapid learning (Ardichvili et al. 2003), and therefore are able to exploit imperfections in prior knowledge distribution (Mainela et al. 2018). The opportunity creation perspective, which relies on the Schumpeterian approach to entrepreneurial opportunities (Schumpeter 1934), regards opportunity creation as a proactive process (Kontinen and Ojala 2011a; Kauppinen and Juho 
2012). In this perspective, opportunities have no objective existence, but instead are the result of the active role of entrepreneurs, who are willing and able to turn new ideas into marketable products, thus creating market disruptions (Schumpeter 1934). Entrepreneurs create new opportunities either by undertaking actions (Alvarez and Barney 2007; Oyson and Whittaker 2015) or by employing their imagination (Shane and Venkataraman 2000; Oyson and Whittaker 2015).

Although the boundary delimitation between opportunity discovery and opportunity creation is commonly shared in international entrepreneurship research (Alvarez and Barney 2007; Mainela et al. 2014), there is also a broad agreement in the literature on the complementarity of these views (Johanson and Vahlne 2009; Hilmersson and Papaioannou 2015; Oyson and Whittaker 2015). Hence, some opportunities are discovered while others are created (Oviatt and McDougall 2005; Zahra 2008; Oyson and Whittaker 2015), Furthermore, both modes of opportunity identification can coexist (Muzychenko and Liesch 2015; Oyson and Whittaker 2015; Chetty et al. 2018), as serendipity in opportunity discovery complements strategically planned systematic activities in opportunity creation (Crick and Spence 2005; Muzychenko and Liesch 2015). In addition, opportunity discovery can enable opportunity creation and vice versa (Zahra 2008; Welter and Alvarez 2015; Chetty et al. 2018). Thus, Chandra et al. (2015) and Zaefarian et al. (2016) observe that primary international opportunities are mostly discovered, whereas subsequent internationally opportunities tend to be created. Chandra et al. (2015) attribute such a move from discovery to creation in international opportunity identification to a gradual shift in entrepreneurial logic from effectuation to causation (Sarasvathy 2001). Contrary to Chandra et al. (2015), Zaefarian et al. (2016) explain such a move by characteristics of the studied firms, such as risk-averseness and long-term orientation. Oyson and Whittaker (2015) find that firms' subsequent international opportunity identification can display various patterns and is facilitated by the experiential knowledge acquired by the firms in the process of primary international opportunity identification. These findings are corroborated by Chetty et al. (2018) who also show that internationalising firms exhibit various trajectories in their move from primary to subsequent international opportunity identification, namely (i) from primary opportunity discovery to subsequent opportunity discovery; (ii) from primary opportunity discovery to subsequent opportunity creation; (iii) from primary opportunity creation to subsequent opportunity discovery; and (iv) from primary opportunity creation to subsequent opportunity creation. Chetty et al. (2018) explain this enabling feature of international opportunities by the mediating role of knowledge and resources as well as the moderating role of networking capabilities and entrepreneurial capabilities.

There is broad agreement among international entrepreneurship scholars on the ambiguity of terminology used to describe the two modes of international opportunity identification (Muzychenko and Liesch 2015; Oyson and Whittaker 2015; Chetty et al. 2018). In addition to discovery and creation, broadly used in the international entrepreneurship literature, they record, among others, recognition, search, perception and development as other terms related to international opportunity identification, which are often used interchangeably (Muzychenko and Liesch 2015; Oyson and Whittaker 2015; Chetty et al. 2018). Analysing various terms related to international opportunity identification, we can observe that recognition is used synonymously for discovery, and search can be used as a substitute for creation (see Table 1). Oyson and Whittaker (2015) find international opportunity discovery to be solely a cognitive activity and associate it with various mental processes, such as perception and recognition. Still 
other international entrepreneurship scholars employ development irrespective to the mode of international opportunity identification (Lorentz and Ghauri 2010).

Chetty et al. (2018), responding to this ambiguity, provide useful definitions of opportunity discovery and opportunity creation. They define opportunity discovery as 'the act or process of perceiving or finding a favourable set of circumstances to create value' and opportunity creation as 'the act or process of shaping or creating a favourable set of circumstances to create value' (Chetty et al. 2018; pp. 70-71). While acknowledging the theoretical value of these definitions, we also see the opportunity to bring in an important nuance to the definition of opportunity creation by drawing on the claims of Chandra et al. (2012) on the influence of entrepreneurial intentionality on firms' willingness and ability to identify and exploit international opportunities. Thus, to make a clearer distinction between the two principal modes of opportunity identification (i.e. opportunity discovery and opportunity creation), we find it beneficial for the purpose of our study to modify Chetty et al.'s (2018) definition of opportunity creation to 'the intentional act or process of crafting a favourable set of circumstances to create value'.

Recent studies have enhanced our knowledge on antecedents of international opportunity identification, such as a firm's prior international experience and knowledge (Chandra et al. 2009; Schweizer et al. 2010; Laperrière and Spence 2015), entrepreneurial orientation (Ripollés-Mélia et al. 2007; Chandra et al. 2009) and networks (Chandra et al. 2009; Ellis 2011; Kontinen and Ojala 2011a, b; Galkina and Chetty 2015). Thus, Chandra et al. (2009) suggest that the degree of international experience and knowledge influence how firms identify their international opportunities. Those firms with no international experience and knowledge are likely to identify their international opportunities by means of discovery, while development of international experience and knowledge contributes to firms' more likely engagement in the process of international opportunity creation (Chandra et al. 2009; Ciravegna et al. 2014). Ripollés-Mélia et al. (2007) and Chandra et al. (2009) emphasise that firms' entrepreneurial orientation plays a central role in identification of international opportunities and find that firms that exhibit a stronger entrepreneurial orientation identify international opportunities more often. In the extant literature, there is a consensus on the vital importance of networks, which enable the acquisition of knowledge and capabilities by firms and thereby influence their identification of international opportunities (Bai and Johanson 2018). This acknowledgement of the central role of various networks in which firms are embedded for their internationalisation has resulted in the adoption of the network approach by international entrepreneurship scholars as a useful theoretical lens to study firms' international opportunity identification (Johanson and Vahlne 2009; Evers and O'Gorman 2011; Kontinen and Ojala 2011a, b; Galkina and Chetty 2015; Bai and Johanson 2018; Leppäaho et al. 2018). Despite a growing body of knowledge on the role of networks in firms' international opportunity identification, the use of networks in this process still remains to some degree a controversial issue (Ciravegna et al. 2014). For instance, different studies highlight the value of different kinds of ties for international opportunity identification. While one group of scholars articulates the importance of business ties for knowledge acquisition and thereby international opportunity identification (Presutti et al. 2007; Blankenburg Holm et al. 2015; Hilmersson and Papaioannou 2015), another emphasises the value of social ties as sources of information and ideas that trigger international opportunity identification (Ellis 2000, 2011; Vasilchenko and Morrish 2011). Furthermore, strong as well as weak ties are considered 
Table 1 Terms used to describe dimensions of international opportunity (IO) identification in international entrepreneurship (IE) literature

\begin{tabular}{ll}
\hline Category Terms & $\begin{array}{l}\text { Definition/meaning (if available) } O R \\
\text { approach/view adopted } O R \text { the way } \\
\text { the respective term is used in IE } \\
\text { literature }\end{array}$
\end{tabular}

Mainstream Discovery
terms for IO
identification
modes

\section{'[...] recognizing or discovering a "fit" between particular market needs and specified resources'}

Entrepreneur's reactive behaviour in Nordman and Melén (2008) IO identification

'The discovery view focuses on the elements of the social situation, such as resources and markets determined as means and ends in international opportunities'

'Act or process of perceiving or finding a favorable set of circumstances to create value'

Passive search for IO

'[...] spontaneous and unplanned cognitive process'

Used contextually and interchangeably with IO identification

Used contextually and interchangeably with IO recognition

Elaboration on Kirzner's (1997) approach

Elaboration on Mainela's et al. (2014) view

No specific definition; the term is nuanced on the basis of interpretation and integration of different studies within IE and entrepreneurship domains

Creation

Chetty et al. (2018, p. 70)

Zahra et al. (2005)

Alvarez and Barney (2007); taker (2015)

Formation of 'a new "fit" between
Ardichvili et al. (2003, p. 109)

Mainela et al. (2014, p. 120)

Kontinen and Ojala (2011b, p. 494)

Oyson and Whittaker (2015, p. 329)

Oviatt and McDougall (2005)

Chandra et al. (2009); Schweizer et al. (2010); Andersson and Evers (2015); Oyson and Whit-

Blankenburg Holm et al. (2015)

Oviatt and McDougall (2005); Ellis (2011); Laperrière and Spence (2015); Muzychenko and Liesch (2015); Zaefarian et al. (2016)

Ardichvili et al. (2003, p. 110) earlier separated market needs and resources'

Result of enactment, i.e. IO can only Zahra et al. (2005, p. 140) be created when it is exploited

'The creation view focuses on the Mainela et al. (2014, p. 120) acting and interacting' in the process of IO identification

'[...] purposive and deliberate process involving both cognition and behaviour' 
Table 1 (continued)

\begin{tabular}{ll} 
Category Terms & $\begin{array}{l}\text { Definition/meaning (if available) } O R \\
\text { approach/view adopted } O R \text { the way } \\
\text { the respective term is used in IE } \\
\text { literature }\end{array}$ \\
\hline
\end{tabular}

'[...] act or process of shaping or creating a favourable set of circumstances to create value'

Elaboration on Schumpeter's (1934) approach

Elaboration on Mainela's et al. (2014) view

No specific definition; the term is nuanced on the basis of interpretation and integrations of different studies within IE and entrepreneurship domains

Alternative terms for IO identification modes
Recognition

Entails opportunity perception, discovery and creation

Entrepreneur's mental process, which is a part of IO discovery

'[...] realization that a market opportunity objectively exists for someone'

Used contextually and interchangeably with IO identification

Used contextually and interchangeably with IO discovery

Search

Entrepreneur's proactive behaviour in IO identification

Active search

Deliberate search

Purposeful search

Systematic search

Used as the opposite for IO discovery

No specific definition; the term is nuanced on the basis of interpretation and integrations of different studies within IE and entrepreneurship domains
Chetty et al. (2018, p. 71)

Alvarez and Barney (2007);

Schweizer et al. (2010);

Andersson and Evers (2015)

Blankenburg Holm et al. (2015)

Oviatt and McDougall (2005);

Laperrière and Spence (2015)

Ardichvili et al. (2003, p. 110)

Oyson and Whittaker (2015, p. 328)

Reuber et al. (2018, p. 397)

Oviatt and McDougall (2005); Zahra et al. (2005); Nordman and Melén (2008); Schweizer et al. (2010); Ellis (2011); Kontinen and Ojala (2011b); Andersson and Evers (2015); Blankenburg Holm et al. (2015); Laperrière and Spence (2015); Zaefarian et al. (2016)

Nordman and Melén (2008); Zaefarian et al. (2016)

Nordman and Melén (2008)

Kontinen and Ojala (2011b)

Chandra et al. (2009); Muzychenko and Liesch (2015)

Zaefarian et al. (2016)

Kontinen and Ojala (2011b)

Chandra et al. (2009); Kontinen and Ojala (2011b); Muzychenko and Liesch (2015)

Ellis (2011); Zaefarian et al. (2016) 
Table 1 (continued)

\begin{tabular}{|c|c|c|c|}
\hline Category & Terms & $\begin{array}{l}\text { Definition/meaning (if available) } O R \\
\text { approach/view adopted } O R \text { the way } \\
\text { the respective term is used in IE } \\
\text { literature }\end{array}$ & $\begin{array}{l}\text { Examples in IE literature } \\
\text { (selected references) }\end{array}$ \\
\hline & \multirow[t]{4}{*}{ Perception } & '[...] sensitivity to opportunity' & Ardichvili et al. (2003, p. 110) \\
\hline & & $\begin{array}{l}\text { Starting point in IO development; } \\
\text { related to cognitive capabilities } \\
\text { and expectations of entrepreneurs }\end{array}$ & Lorentz and Ghauri (2010, p. 241) \\
\hline & & $\begin{array}{l}\text { Cognitive process shaped by 'what } \\
\text { we know (i.e. knowledge), by } \\
\text { what we think we know, and what } \\
\text { we do not know' }\end{array}$ & Renko et al. (2012, p. 1239) \\
\hline & & $\begin{array}{l}\text { Mental process, which is a part of IO } \\
\text { discovery }\end{array}$ & Oyson and Whittaker $(2015$, p. 328$)$ \\
\hline & \multirow[t]{3}{*}{ Development } & $\begin{array}{l}\text { '[...] continuous, proactive process } \\
\text { essential to the formation of a } \\
\text { business' }\end{array}$ & Ardichvili et al. (2003; p. 109) \\
\hline & & $\begin{array}{l}\text { '...] creating, combining or utilizing } \\
\text { more effectively new or existing } \\
\text { resources, and the coordination of } \\
\text { their flows, through new or } \\
\text { enhanced activity links with } \\
\text { suppliers, distributors, or other } \\
\text { supporting actors such as logistics } \\
\text { service providers' }\end{array}$ & Lorentz and Ghauri (2010, p. 241) \\
\hline & & $\begin{array}{l}\text { Two-stage process consisting of IO } \\
\text { recognition and exploitation }\end{array}$ & $\begin{array}{l}\text { Blankenburg Holm et al. (2015, p. } \\
\text { 342) }\end{array}$ \\
\hline \multirow[t]{3}{*}{ IO type } & \multirow[t]{2}{*}{ Primary/initial } & $\begin{array}{l}\text { Opportunity to enter international } \\
\text { markets for the first time }\end{array}$ & $\begin{array}{l}\text { Chandra et al. }(2009, \text { p. } 31) \text {; Oyson } \\
\text { and Whittaker }(2015, \text { p. } 310)\end{array}$ \\
\hline & & First or first-time IO & $\begin{array}{l}\text { Chandra et al. (2012); Laperrière } \\
\text { and Spence (2015); Zaefarian } \\
\text { et al. (2016); Reuber et al. (2017) }\end{array}$ \\
\hline & \multirow[t]{4}{*}{ Subsequent } & $\begin{array}{l}\text { IO succeeding initial/first/first-time } \\
\text { IO }\end{array}$ & $\begin{array}{l}\text { Chandra et al. (2009, 2012); } \\
\text { Laperrière and Spence (2015); } \\
\text { Oyson and Whittaker (2015); } \\
\text { Zaefarian et al. (2016); Reuber } \\
\text { et al. (2017) }\end{array}$ \\
\hline \multirow[t]{3}{*}{$\begin{array}{l}\text { Duality of IO } \\
\text { identification } \\
\text { modes }\end{array}$} & & $\begin{array}{l}\text { Discovery and creation modes of IO } \\
\text { identification are not mutually } \\
\text { exclusive }\end{array}$ & $\begin{array}{l}\text { Mainela et al. (2014); Laperrière } \\
\text { and Spence (2015); Chetty et al. } \\
\text { (2018) }\end{array}$ \\
\hline & & $\begin{array}{l}\text { Some IO can be discovered, while } \\
\text { others are results of creation by } \\
\text { entrepreneurs }\end{array}$ & Oyson and Whittaker (2015) \\
\hline & & $\begin{array}{l}\text { The outcomes of one IO } \\
\text { identification and pursuit become } \\
\text { the antecedents of the } \\
\text { identification and pursuit of } \\
\text { subsequent IO }\end{array}$ & $\begin{array}{l}\text { Reuber et al. (2017); } \\
\text { Chetty et al. (2018) }\end{array}$ \\
\hline
\end{tabular}


to be important for identification of international opportunities, and in this respect the extant research has generated contradictory results (Chandra et al. 2009; Evers and O'Gorman 2011; Kontinen and Ojala 2011a). This discrepancy in empirical findings indicates a lack in our understanding of how the use of networks in the process of international opportunity identification varies contextually (Reuber et al. 2017). Subsequently, international entrepreneurship scholars are encouraged to explore various contexts of firm internationalisation as well as consider studying a greater variety of firms (Reuber et al. 2017). Since industries differ in terms of their knowledge intensiveness, entry barriers, requirements for product standardisation/adaptation, etc., 'focus on industries is likely to yield valuable insights on how firms pursue international opportunities' (Reuber et al. 2017, p. 415). Thus, research on underlying mechanisms of identification of international opportunities by late internationalising firms operating in industries with low and medium knowledge intensity has a potential to make new contributions to the field (Reuber et al. 2017; Chetty et al. 2018).

\section{Networks in international opportunity identification}

Networks, representing connections between various actors (both individuals and organisations) are broadly considered crucial for firm internationalisation (Coviello 2006; Johanson and Vahlne 2009; Andersson et al. 2013), enabling them to both identify international opportunities and exploit them (Johanson and Vahlne 2009; Chandra et al. 2009; Kontinen and Ojala 2011a; Hohenthal et al. 2014). Furthermore, Andersson et al. (2005) argue that the characteristics of the networks surrounding the firm have a profound impact on how the firm finds opportunities. Despite a large body of knowledge on networks in firm internationalisation (see, e.g. Jones et al. 2011), only a few studies observe the role of networks in the opportunity identification phase of firm internationalisation (Bai and Johanson 2018).

Networks are primarily considered sources of information, knowledge and experience, which support firms in identification of international opportunities (Chandra et al. 2009; Tolstoy 2010; Evers and O'Gorman 2011; Andersson et al. 2013). In this process, firms enter new networks, create new relationships, establish positions in relation to other firms and develop relationships in those networks as well as connect different networks in both the country of origin and countries of expansion (Chetty and Blankenburg-Holm 2000; Chandra et al. 2009; Hilmersson and Jansson 2012; Blankenburg Holm et al. 2015). In the extant literature, networks are categorised in a number of ways depending on the purpose, level of analysis and context.

First, networks are categorised based on the type of network ties (Kontinen and Ojala 2011a). Eberhard and Craig (2013), discussing the results of a review of the network literature, state that networks are commonly considered to fall into one of two main categories: inter-organisational and inter-personal. Inter-organisational networks are characterised by having formally contracted, collaborative arrangements within value chain activities (Westhead et al. 2004), also known in the literature as business networks or formal networks (O'Donnell et al. 2001). Inter-personal networks, also labelled as social networks or informal networks (O'Donnell et al. 2001), are related to personal relationships of entrepreneurs and managers with either friends or family members (Coviello 2006). In addition to these two types of networks, which, for the purpose of this study, we call business and social networks, we also consider 
institutional networks, based on a modified definition of intermediary ties provided by Ojala (2009) and Kontinen and Ojala (2011a). We use the term 'institutional network' (Belso-Martínez 2006; Oparaocha 2015) to refer to a set of a firm's ties with other organisational actors, with whom the firm does not have any transactional activities but has either formal or informal collaborative arrangements. Such actors aiming at facilitating exchanges between firms may comprise but are not limited to entrepreneurship and small business support organisations, academic institutions, government agencies and non-governmental organisations (Oparaocha 2015). Individual studies highlight the importance of different kinds of networks for international opportunity identification. While one group of scholars articulates the importance of business networks for knowledge acquisition and international opportunity identification (Presutti et al. 2007; Kontinen and Ojala 2011b; Blankenburg Holm et al. 2015), another emphasises the value of social networks as sources of information and ideas that trigger international opportunity identification (Ellis 2000; Ellis 2011; Vasilchenko and Morrish 2011). Social ties, representing inter-personal relationships, are seen as suppliers of information that otherwise cannot be acquired, for instance, through a systematic market search (Sharma et al. 2006). Institutional networks appear to be beneficial for firms that are actively involved in the process of international opportunity creation by searching for foreign market information, partners, funding or advisory and knowledgesupport services (Oparaocha 2015).

Second, networks are also categorised on the basis of the strength of their ties, which can be either strong or weak (Granovetter 1973, 1983). Differences between strong and weak ties in a network are explained using four criteria: the frequency of contacts, the emotional intensity of relationships, the degree of intimacy and reciprocal commitments between the network actors. Whereas strong ties are associated with long-term, intensive relationships based on trust and commitment between network actors involved, weak ties refer to infrequent, irregular and non-affective relationships between network actors (Elfring and Hulsink 2003). International opportunity identification can be the result of exploitation of both strong and weak ties (Chandra et al. 2012). While the function of weak ties is considered to bridge gaps between networks that introduce new knowledge and ideas, the function of strong ties is considered to 'deliver' new knowledge and ideas entering a network to those who are able to make use of them (Chandra et al. 2012). Consequently, weak ties are likely to enable firms to discover international opportunities (Chandra et al. 2009; Kontinen and Ojala 2011a; Masiello and Izzo 2019), whereas strong ties are likely to be used by those who intentionally search for new international opportunities (Masiello and Izzo 2019).

Third, based on the locality of ties, a distinction can be drawn between international and local networks (Leppäaho et al. 2018). Whereas international networks comprise actors originating from a number of countries, local/domestic networks are clustered in the region (Andersson et al. 2013). Previous research highlights the strategic importance of international networks in identification of international opportunities due to these networks' enabling role in foreign market knowledge generation and sharing among their actors (Tolstoy 2010; Evers and O'Gorman 2011; Andersson et al. 2013). However, international networks seem to be more important for early and rapidly internationalising firms operating in high-technology industries (Sharma and Blomstermo 2003; Oviatt and McDougall 2005; Andersson et al. 2013) than for mature (late internationalising) firms operating in low- and medium-technology industries (Francioni et al. 2017). Local 
networks have gained substantially less attention in the international entrepreneurship literature (Andersson et al. 2013; Leppäaho et al. 2018). Leppäaho et al. (2018) deduce from the literature that local networks might be both beneficial and detrimental for small firm internationalisation. On the one hand, local networks might facilitate international opportunity identification either by facilitating firms to follow their local customers expanding to foreign markets or by acquiring networking skills from their domestic ties. On the other hand, large local partners, focusing on the domestic market, might hamper firms' internationalisation ambitions (Milanov and Fernhaber 2014) or acquiring knowledge about internationalisation might take longer time because of the need to unlearn old routines from the local network ties (Sharma and Blomstermo 2003).

In addition, in view of growth and decay of ties (Peiris et al. 2012) as well as development of weak ties into strong ones (Kontinen and Ojala 2011a), several studies highlight the importance of both new (Kontinen and Ojala 2011a) and existing (Coviello and Munro 1995, 1997) ties for the identification of international opportunities by different kinds of firms such as those operating in high-technology sectors (e.g. Laurell et al. 2017) and in low- and medium-technology sectors (e.g. Kontinen and Ojala 2011a). In the process of international opportunity, identification firms without suitable networks extend their ties by forming new relationships (Ojala 2009) based on either a systematic search for a suitable partner or ad hoc events (Johanson and Vahlne 2006). Thus, ties extension can lead to both international opportunity creation (in case of an active search for and initiation of new relationships) and discovery (in case of a reaction to initiations coming from outside an existing network). Firms can also identify international opportunities via their existing ties which prompt new contacts and help firms with establishment of new relationships (Coviello and Munro 1995). Firms' reliance on their existing ties in the process of international opportunity identification is likely to require ties strengthening (Coviello 2006), as the willingness to offer assistance to actors within a network is based on the earlier history of their recurrent interactions (Kontinen and Ojala 2011a), which is attributable to strong ties (Granovetter 1973). A summary of the discussed above network ties categories is provided in Table 2 .

\section{Mature industry context and firm late internationalisation}

International entrepreneurship literature clearly articulates the importance of industry contexts for firm internationalisation as well as indicates varieties of internationalisation patterns for firms operating in different industry sectors (Andersson 2004; Fernhaber et al. 2007; Laurell et al. 2013). However, while calling for extending its domain to 'traditional' industry sectors (Peiris et al. 2012; Reuber et al. 2017), international entrepreneurship research still remains predisposed to the study of firms operating in high-technology and knowledge-intensive sectors (Jones et al. 2011; Peiris et al. 2012; Laurell et al. 2013). 'Traditional' (Bell et al. 2004; Magnani and Zucchella 2019; Masiello and Izzo 2019) and 'mature' industries (Andersson 2004; Evers 2011; Andersson et al. 2014), which are usually characterised by a lower knowledge intensity (such as low- and mediumtechnology sectors), still remain a largely understudied context in international entrepreneurship (Evers 2010, 2011; Masiello and Izzo 2019). 
Table 2 Network characteristics used in international entrepreneurship literature

\begin{tabular}{|c|c|c|}
\hline $\begin{array}{l}\text { Network ties } \\
\text { descriptor }\end{array}$ & Categories & Definition/key features \\
\hline \multirow[t]{3}{*}{ Type of ties } & $\begin{array}{l}\text { Business } \\
\text { networks }\end{array}$ & $\begin{array}{l}\text { Formally contracted, collaborative inter-organisational arrangements } \\
\text { within value chain activities (O'Donnell et al. 2001; } \\
\text { Westhead et al. 2004; Eberhard and Craig 2013) }\end{array}$ \\
\hline & $\begin{array}{l}\text { Social } \\
\text { networks }\end{array}$ & $\begin{array}{l}\text { Informal, personal relationships of entrepreneurs and managers with either } \\
\text { friends or family members (O’Donnell et al. 2001; Coviello 2006; } \\
\text { Eberhard and Craig 2013) }\end{array}$ \\
\hline & $\begin{array}{r}\text { Institutional } \\
\text { networks }\end{array}$ & $\begin{array}{l}\text { Set of ties with organisational actors, with whom the firm does not have } \\
\text { any transactional activities but has either formal or informal } \\
\text { collaborative arrangements (Belso-Martínez 2006; Ojala 2009; } \\
\text { Kontinen and Ojala 2011a; Oparaocha 2015) }\end{array}$ \\
\hline \multirow[t]{2}{*}{ Strength of ties } & Strong ties & $\begin{array}{l}\text { Long-term, intensive relationships based on trust and commitment } \\
\text { between network actors involved (Elfring and Hulsink 2003) }\end{array}$ \\
\hline & Weak ties & $\begin{array}{l}\text { Infrequent, irregular and non-affective relationships between network } \\
\text { actors involved (Elfring and Hulsink 2003) }\end{array}$ \\
\hline \multirow[t]{2}{*}{ Locality of ties } & $\begin{array}{c}\text { International } \\
\text { networks }\end{array}$ & $\begin{array}{l}\text { Networks comprising actors originating from a number of countries } \\
\text { (Andersson et al. 2013) }\end{array}$ \\
\hline & Local networks & $\begin{array}{l}\text { Networks, comprising actors originating from the same country/region } \\
\text { (Andersson et al. 2013) }\end{array}$ \\
\hline \multirow[t]{2}{*}{$\begin{array}{l}\text { Development } \\
\text { of ties }\end{array}$} & New ties & $\begin{array}{l}\text { Ties formed as a result of network extension, i.e. establishing new } \\
\text { relationships (Ojala 2009) }\end{array}$ \\
\hline & Existing ties & $\begin{array}{l}\text { Used as the opposite for new ties (Coviello and Munro 1995, 1997); firms' } \\
\text { reliance on their existing ties in the process of international opportunity } \\
\text { identification might require ties strengthening (Coviello 2006) }\end{array}$ \\
\hline
\end{tabular}

In accordance with OECD (2011) industry classifications based on the level of R\&D intensities, low-technology industries are characterised by low levels of investment in R\&D (less than $1 \%$ of turnover) and comprise among others textiles, leather and food. Medium-technology industries include those investing between 1 and $4 \%$ of turnover in R\&D (e.g. chemicals, vehicles, machinery manufacturing, repair and installation). Being more challenged by the globalisation processes and suffering from easy imitability of their products (Hirsch-Kreinsen 2008), firms in these mature industries generally remain domestic. However, among such firms, there is a small cohort of those who seem to be better equipped to spot international opportunities and act on them (OECD 2018). Perks and Hughes (2008), based on the study of established firms in industries with different levels of knowledge intensity (medium-technology and hightechnology), find that a decision to internationalise is strongly influenced by the entrepreneurial manager's connection with the customer, tacit knowledge and product-service complexity.

While there are several studies focusing on early and rapidly internationalising firms in low-tech industries (Sullivan-Mort and Weerawardena 2006; Evers 2010, 2011) and medium-tech industries (Andersson 2004; Bell et al. 2004; Belso-Martínez 2006), less attention has been paid by international entrepreneurship scholars to late internationalising firms in mature industries (Bhagavatula et al. 2010; Kontinen and Ojala 2011b; Veglio and Zucchella 2015; Masiello and Izzo 2019) with single studies 
addressing opportunity identification by these firms (Kontinen and Ojala 2011b; Francioni et al. 2017; Galan and Torsein 2018; Masiello and Izzo 2019).

Late internationalising firms, in international entrepreneurship literature also called late starters (Johanson and Mattsson 1988), latecomers (Peiris et al. 2012), late internationals (Aspelund and Moen 2005), enduring globals and mature exporters (Peiris et al. 2012), are defined using a number of criteria, of which time of first market entry and the degree of internationalisation measure as the percentage of foreign sales in total sales are the most commonly used (Peiris et al. 2012). With regard to the time of first market entry, timeframes span between more than 3 years (Jantunen et al. 2008) and more than 28 years after firm inception (Sheppard and McNaughton 2012, see Francioni et al. 2017) with 6 years being used to distinguish between early and mature exporters (Peiris et al. 2012). As for the degree of internationalisation, it is commonly agreed that such firms should achieve an export share of at least $25 \%$ within the first 3 years after starting internationalisation (Francioni et al. 2017). However, to distinguish mature exporters from enduring globals, Peiris et al. (2012) suggest a threshold at the level of 70\%. Having reviewed empirical studies in the field of international entrepreneurship published between 1993 and 2012, Peiris et al. (2012) observe that the born globals show an average foreign sales to total sales ratio of $>70 \%$ within the first 3 years of operation. Finding this observation to be in line with international business literature and considering enduring globals to be quite similar to born globals in terms of the degree of internationalisation, Peiris et al. (2012) find the threshold to be useful for distinguishing enduring globals from mature exporters and applicable for empirical studies in international entrepreneurship.

Building on the arguments of Francioni et al. (2017) and Peiris et al. (2012), we apply the following thresholds for mature firms in this study: more than 6 years after inception for the time of first market entry and at least 25\% but less than $70 \%$ for the degree of internationalisation in terms of share of foreign sales in total sales.

Andersson (2004) finds that firms operating in mature industries, which start to internationalise quite late, differ in terms of their earlier and later stages of internationalisation. This suggests that firms in these industries might identify their primary and subsequent international opportunities in different ways. Along with the entrepreneurs' proactiveness, which is important at both earlier and later stages of internationalisation, Andersson (2004) highlights the role of the entrepreneurs' experiential learning within social and business networks, with higher importance of business networks at the later stages of internationalisation. In line with Andersson (2004), Kontinen and Ojala (2011b) also highlight the role of business ties in the internationalisation of mature firms in traditional industries. They find, however, that the process of international opportunity identification by such firms is the result of entrepreneurs' alertness rather than proactiveness. Bai and Johanson (2018), based on a sample of both early and late internationalising firms, find that networks function mainly as mediators for identification of international opportunities, which are mainly discovered and rarely actively searched via networks. These findings are in line with of Masiello and Izzo (2019), who focused on mature firms in a low-technology industry. As for the ties' strength, previous research generates quite contradictory findings with respect to firms operating in mature industries. While weak ties are generally considered to be more important for opportunity identification (Kontinen and Ojala 2011a; 
Masiello and Izzo 2019), some findings point to the crucial role of strong ties in this process (Bai and Johanson 2018; Masiello and Izzo 2019).

Francioni et al. (2017), based on the study of mature firms in a traditional industry (food and beverages/wines), highlight the importance of personal and business networks for firm internationalisation in general and active efforts of entrepreneurs in the extension of the networks by establishing new relationships attending trade shows in particular. Veglio and Zucchella (2015) in their study of small exporting firms in other traditional industries (apparel, leather products) consider trade shows a prevalent way for such firms to increase their visibility and establish commercial contacts. Late internationalising firms in traditional industries seem to lack strategy in terms of various foreign activities (Francioni et al. 2017), which indicates that they may be predisposed to identify both their primary and their secondary opportunities by discovery (Masiello and Izzo 2019).

In contrast to the afore-discussed studies, Magnani and Zucchella (2019), studying among others' established firms in traditional industries, find no links between these firms' networking and internationalisation processes. Instead, internationalisation of such firms is regarded as the result of adoption by them a global niche strategy, which is 'neither a follow-the-customer approach nor a reactive posture' (Magnani and Zucchella 2019). On the contrary, this strategy implies that small firms operating in traditional industries identify their international opportunities in a proactive way by focusing on their customers' needs, anticipating them and providing solutions through customer interactions (Magnani and Zucchella 2019).

In order to generate a better understanding of how mature small firms operating in mature industries identify their primary and subsequent international opportunities, we put forward a conceptual framework by integrating types of international opportunities, modes of international opportunity identification and network characteristics (see Fig. 1).

\section{Methodology}

\section{Research design and case selection}

The aim of this study is, embracing a network approach, to advance our knowledge of how mature firms operating in mature industries identify their international opportunities. Given the current limited understanding of international opportunity identification by late internationalising firms in medium-technology industries, adoption of a qualitative research strategy for this study appears to be most appropriate. To achieve our objective, we employ a case study design, which is considered to be particularly useful for addressing a broad range of questions including 'how' and 'why' as well as for understanding the dynamics within specific settings (Eisenhardt 1989; Eisenhardt and Graebner 2007). It also offers an opportunity for a deep understanding of the studied cases as well as learning as much as possible from them (Stake 2003). An additional motivation to adopt a case study design stems from its wide application in holistic explorations of both cognitive and behavioural facets of international entrepreneurship (see the review of the studies within the research domain by Jones et al. (2011) and Peiris et al. (2012)). 


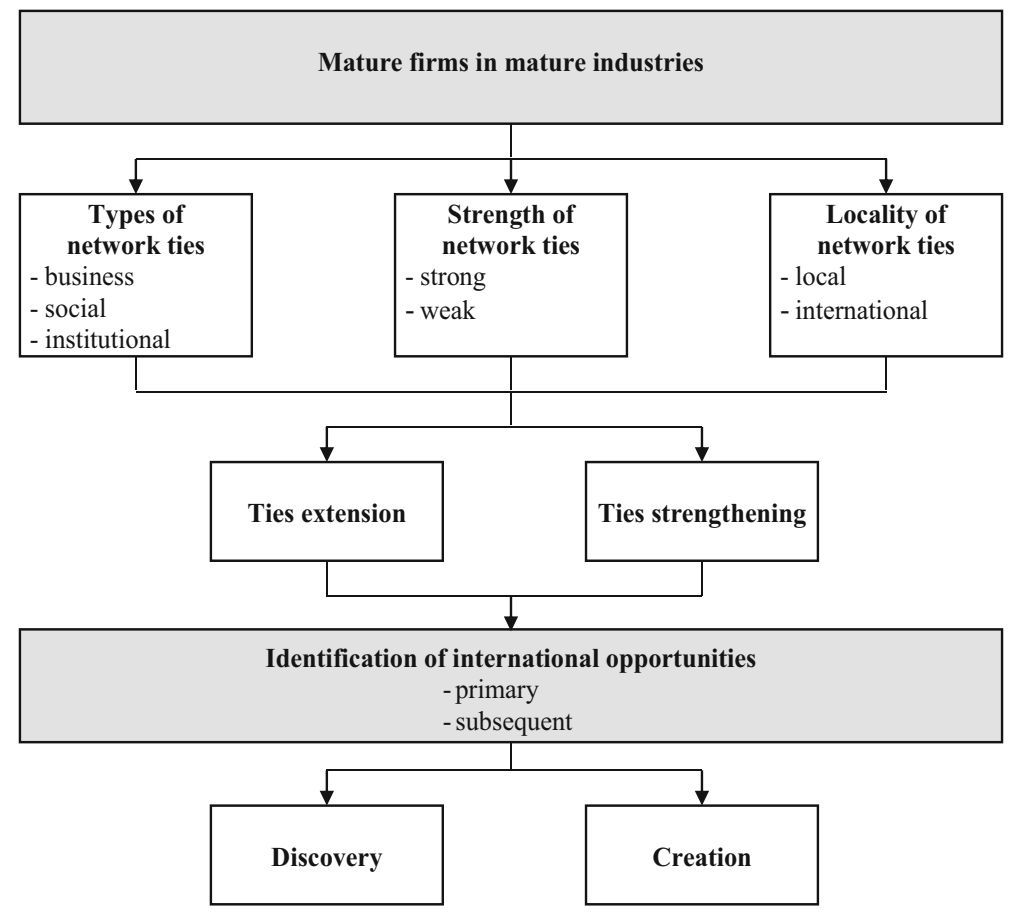

Fig. 1 Conceptual framework

The case studies were performed within a large-scale EU-funded project, which involved about forty participants from Sweden and Norway (26 mostly small firms operating predominantly in industries with low and medium knowledge intensity, eight municipalities, two universities, two entrepreneurship support organisations and two not-for-profit organisations). This consortium seemed to fit our study objectives very well. Using as a starting point our theoretical assumptions about the crucial role of networks in identification of international opportunities by small firms, we considered it beneficial for achieving our research objectives to perform case studies on the basis of firms that had been a part of both business and institutional as well as local and international networks. ${ }^{1}$ The project, which involved different types of stakeholders from two countries displaying a high degree of political, social and cultural similarities (Lööf et al. 2001), provided us with a unique opportunity to find case firms suitable for our research and approach them.

For this study, the firms were purposively selected (Patton 2002). The cases were chosen based on the anticipation to obtain rich evidence and deep insights into the studied phenomenon (Stake 2003). The following criteria were applied in the process of case selection:

(i) Size: The firm should be small in size, i.e. have less than 50 employees, as well as be consistent with other criteria employed by the European Commission in the definition of the small enterprise (EC 2003).

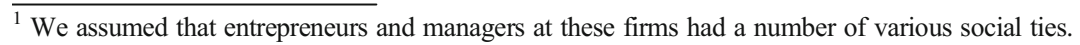


(ii) Industry: The firm should operate in a medium-technology industry (OECD 2011).

(iii) Independence: The firm should not be a part of a larger domestic or international firm.

(iv) Direction of internationalisation: The firm should be involved in outward international activities, which are of greater interest to international entrepreneurship research than inward international activities due to their greater complexity, resource requirements and stronger interest from the business community (Oyson and Whittaker 2015).

(v) Maturity/Time of first market entry: The firm should be possible to class as a mature exporter in terms of Peiris et al. (2012). It means that the firm should enter its first international market no earlier than 6 years after its inception.

(vi) Degree of internationalisation: The firm should have at least 25\% (Francioni et al. 2017) but less than $70 \%$ of its total sales coming from its foreign markets (Peiris et al. 2012).

(vii) Potential contribution: The firms' informant(s) should be willing and able to provide information about all international opportunities the firm has identified.

We started the selection of case firms by screening the websites of all 26 firms participating in the project. The initial screening phase allowed us to exclude those firms who only served their domestic markets, had more than 50 employees, did not operate in medium-technology industries, were a part of a larger domestic or international firm or were involved in inward international activities. After the screening phase, we identified 17 firms which seemed to fulfil our selection criteria. Thereafter, we approached managers of these firms at one of the project network meetings, explaining the purpose of the study, verifying their fulfilment of the rest of our selection criteria and inviting them to contribute to our study as informants. After this stage, we considered 13 firms as possible candidates for selection to our study. The final choice of cases was mainly influenced by being able to interview a key person(s) who played a vital role in the process of international opportunity identification. However, in one case, which we considered exceptionally interesting for our study due to the combination of long time (about 70 years) elapsed between firm inception and the first international opportunity identification, and a high scope of internationalisation, which is quite unusual for late internationalisers (Peiris et al. 2012), we were only able to get in touch with the current (third) generation of owners, who were not directly responsible for the primary international opportunity identification. In this particular case, the primary international opportunity was identified by the owner of the second generation approximately 30 years before our study was conducted. Nevertheless, since this firm has been owned and managed by the same family from the inception, and the current generation of owners were privy to family business as future successors at the time when the first international opportunity was identified, we decided to include this interesting case (Alpha) in our study. Inspired by Kontinen and Ojala (2011a) who studied international opportunity identification of family firms with a long time span between their inception and first international opportunity identification, we equipped ourselves with guidelines for retrospective studies provided by Miller et al. (1997) and were prepared to adhere to them. 


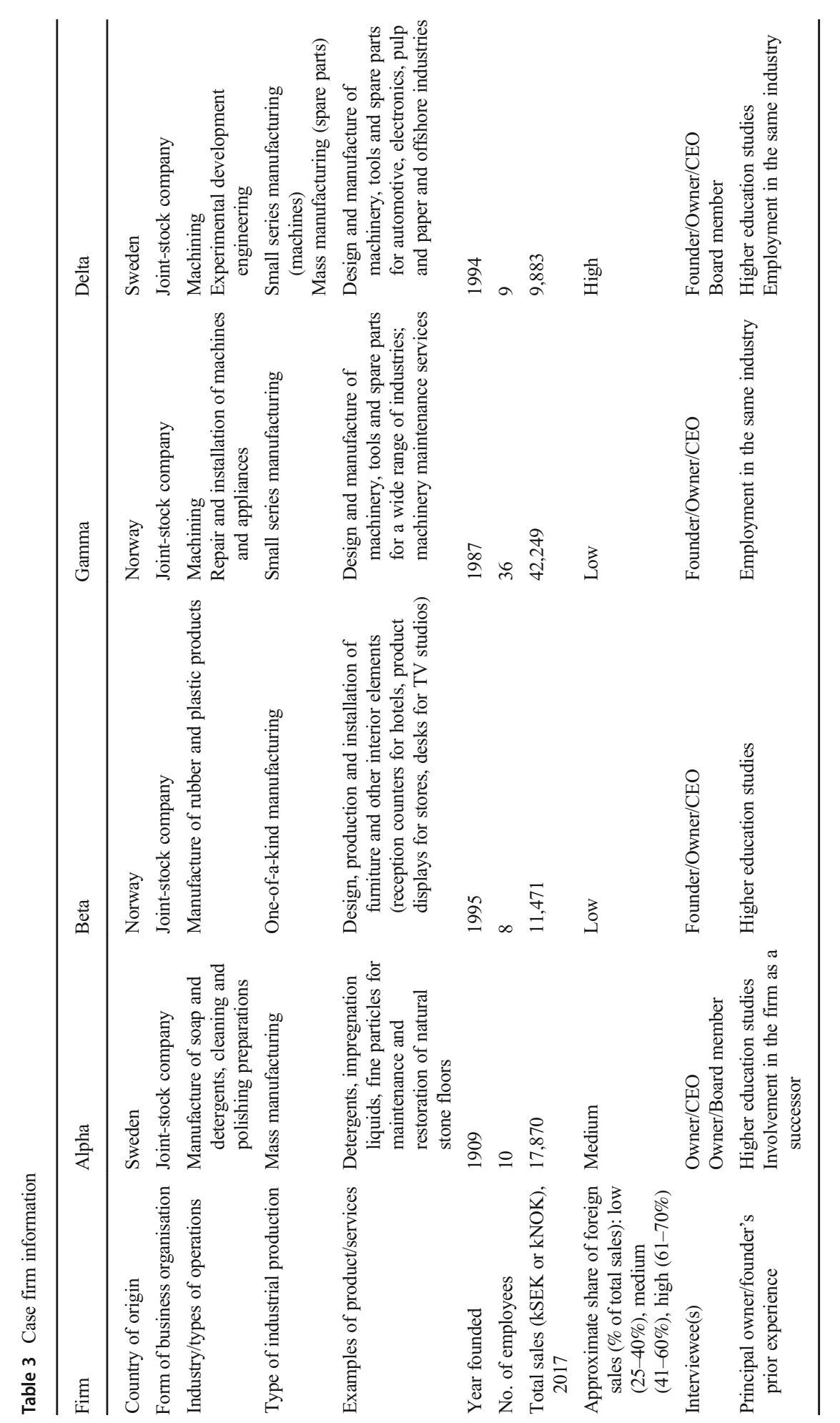


Following recommendations by Eisenhardt (1989) to select between four and ten cases for a multiple case study, we selected four firms to our final sample. Information about the case firms is presented in Table 3.

\section{Data collection}

Following Yin's (2014) guiding principles for data collection in case study research, we considered different sources of data. First, we collected data using face-to-face, semistructured, in-depth interviews with informants from the four focal firms. Since all firms selected for the study are owner-managed, the interviews were conducted with owner-managers or founder-managers of these firms. In two cases (Alpha and Delta), we benefited from the insights of an additional informant who served as a board member. Main interviews with our key informants were conducted onsite during April-October 2017 and lasted between 1 and $2 \mathrm{~h}$.

We started our main interviews by asking our informants to recall how they came across their first opportunity to enter a foreign market. The follow-up questions sought to hear about the outcomes of their first international opportunity; how they came across subsequent international opportunities; how they entered international markets; what made their international expansion possible and successful; what, how and from whom they learnt; with whom and how they built and developed their relationships; and how their experience with identification and exploitation of their first opportunity affected the subsequent internationalisation. We also asked about those opportunities which had not been realised. During the main interviews, we also documented the history of the firms. All this enabled us to track the process and patterns of the firms' international expansion. Since in one case (Alpha) the interview was focused on an event from the fairly distant past, we followed the guidelines for retrospective studies given by Miller et al. (1997). Specifically, we (i) used two informants for this firm and compared information provided by them; (ii) asked about concrete events and facts; (iii) encouraged informants to give precise information by providing explanation about the value of their contributions; and (iv) utilised the archival documents of the firm to facilitate recall of events (e.g. photos, which capture all milestones in the firm history, date back to the year of inception and are partially available via the firm's website, patent registration certificates and international standard compliance certificates).

These main interviews were complemented with shorter (between 20 and $30 \mathrm{~min}$ ) face-to-face interviews with largely the same informants representing all focal firms, which were conducted in connection with a number of network meetings within the project from April 2017 to October 2018. The complementary interviews had a threefold purpose. First, we sought to supplement our data with more details filling in the gaps in the data we had found. Second, we aspired to get updates on international opportunities that were identified by the focal firms after we conducted the main interviews with them. Finally, we performed participant validations to increase the consistency and credibility of our research (Tracy 2010).

All main interviews were digitally recorded and transcribed verbatim using NVivo software (version 11). While conducting complementary interviews, the authors took notes, which were transferred to electronic text documents and then relocated to the study project in NVivo.

Additional data were collected via the firms' websites and from the content created by them in the social media they were active in. The latter was done due to the growing 
importance of social media networks for business relationship development (Quinton and Wilson 2016) as well as their potential for data collection and analysis (Lewis et al. 2008). The websites and social media content were explored to better understand the sequence of events and actions, which led to international opportunity identification and the scope and structure of the firms' networks, as well as to triangulate information obtained during the interviews and to corroborate the evidence provided by the study participants (Yin 2014).

\section{Data analysis}

The analysis of the collected data was performed in two steps. First, within-case analysis (Eisenhardt 1989) was done to map the firms' international opportunity identification. We started from the identification of main events (Buttriss and Wilkinson 2006) related to the firms' international expansion as well as their attributes and underlying mechanisms. To increase transparency of the analysis of our qualitative data as well as establish a comprehensive data structure, NVivo software was used (Bazeley and Jackson 2013). In the NVivo working space, we created a case for each focal firm and coded our data using both an a priori and a posteriori logic (Sinkovics et al. 2008). Some initial categories were distilled from the reviewed literature (a priori categories), while others (a posteriori categories) emerged in the result of scrutinised and multi-iterative processing of the data. In this stage of data analysis, we created about 125 independent nodes. During the next step, we went through the established categories, merging nodes and relocating sub-nodes, to control for relationships as well as to eliminate intersections between the categories. After performing this procedure, we reduced the number of independent nodes to 23. This procedure laid grounds for the second, synthesising step of cross-case analysis (Eisenhardt 1989). Cross-case analysis was performed to spot cross-case patterns, replications and differences in the process of identification of international opportunities with respect to the first and subsequent opportunities, as well as the use of various network ties.

\section{Case findings}

The focal firms display different paths of identification of primary as well as subsequent international opportunities. The overview of the case firms' international opportunity identification is presented in Table 4.

Firm Alpha was founded in Sweden in 1909 as a small family firm manufacturing different types of detergents and hygiene products, and it was not until the late 1980s that the firm's owner-manager identified the firms' first international opportunity. This happened after the firm had been taken over by the second generation of the family. The identification of opportunities available overseas was preceded by the development of a new powerful formula for a floor care product, which the firm offered on the domestic market. The new formula was developed during the late 1960 s by one of the ownermanagers, who was a chemist by background, in co-operation with a medical research firm. After numerous trials, the product proved to be particularly effective for cleaning stone and ceramic floors. Expanding to foreign markets was considered strategically 
Table 4 Overview of international opportunity (IO) identification by case firms

\begin{tabular}{|c|c|c|c|c|}
\hline Firm & Alpha & Beta & Gamma & Delta \\
\hline Country of origin & Sweden & Norway & Norway & Sweden \\
\hline Year founded & 1909 & 1995 & 1987 & 1994 \\
\hline 1 st IO & The Netherlands & UK & Sweden & Norway \\
\hline Time of 1 st IO identification & $1980 \mathrm{~s}$ & 2014 & 2010 & 2006 \\
\hline Mode of 1st IO identification & Creation & Discovery & Creation & Discovery \\
\hline 1st IO exploitation & Yes & Yes & Yes & Yes \\
\hline Mode of market entry for 1 st IO & Direct export & Direct export & $\begin{array}{l}\text { Direct } \\
\text { export }\end{array}$ & $\begin{array}{l}\text { Indirect export } \\
\text { Piggybacking }\end{array}$ \\
\hline Subsequent IOs & $\begin{array}{l}\text { Australia } \\
\text { South Korea } \\
\text { Italy } \\
\text { Germany } \\
\text { UK } \\
\text { Norway } \\
\text { Denmark } \\
\text { Ireland } \\
\text { Finland } \\
\text { United Arab } \\
\quad \text { Emirates }\end{array}$ & $\begin{array}{l}\text { Latvia } \\
\text { Lithuania }\end{array}$ & $\begin{array}{l}\text { Poland } \\
\text { Lithuania }\end{array}$ & $\begin{array}{l}\text { Denmark } \\
\text { UK } \\
\text { Germany } \\
\text { The Netherlands } \\
\text { Australia } \\
\text { USA } \\
\text { Mexico } \\
\text { Poland }\end{array}$ \\
\hline $\begin{array}{l}\text { Mode of subsequent IO } \\
\text { identification }\end{array}$ & Creation & Creation & Discovery & Creation \\
\hline 'False' IOs & $\begin{array}{l}\text { France } \\
\text { Spain } \\
\text { Turkey } \\
\text { Croatia } \\
\text { Bosnia } \\
\text { Poland }\end{array}$ & $\begin{array}{l}\text { Italy } \\
\text { The Netherlands } \\
\text { Sweden } \\
\text { Denmark } \\
\text { USA }\end{array}$ & - & $\begin{array}{c}\text { United Arab } \\
\text { Emirates }\end{array}$ \\
\hline
\end{tabular}

important by the firm founders and owner-managers after the new product had been fully developed. Since then international opportunities were actively searched for by the firm.

The most appropriate way to go international was considered to be building strategic relationships with partners overseas. Operating in a 'traditional' industry, where relying on personal contacts was considered very representative, it was decided to invest in regular attendance at the industry's largest trade fairs overseas.

We are very much a niche company but we got a feeling that there were good market opportunities outside Sweden. There are many more stone floor manufactures abroad than in Sweden, like in Italy, France, Spain... So we decided to search for customers via relevant trade shows which are also 'niche' and concentrate on stone floors. The largest trade show, which we considered quite relevant for our detergents, is regularly arranged in Amsterdam, where a lot of both manufactures and agents are represented.

Attendance at the international trade fair in the Netherlands for the first time generated immediate results: the firm found its first international customer, an importer from the Netherlands. Relationships with the importer developed over time and were mainly 
maintained via telephone, fax, post, and later on email and Skype as well as infrequent but regular meetings at the trade fairs (once every 3 years). Building longstanding relationships with the Dutch importer resulted in retaining and developing it into a recurrent customer. Subsequent participation in the same trade show generated other international opportunities for Alpha: export of its products was initiated to South Korea and Australia. A similar model (using this and other trade shows) proved to work well, and export (either direct to end customers or indirect via agents) was initiated to Italy, Germany, UK, Norway, Denmark, Ireland and Finland. After having established relationships with prospects via trade shows, the firm put its efforts into turning them into customers and then into recurring customers.

Some of our overseas customers are small in terms of their contributions to our sales, other are quite large, some (this mainly applies to agents, distributors and wholesalers) have largely increased volumes of their buy-ins. There are those who during this year alone have bought more than they had ever bought before. For example, an Italian wholesaler has already purchased the whole year's production volume, until the end of the year. It is really amazing!

In the early 2000s, Alpha went through the process of organisational restructuring. It all started with changes in the ownership structure, when new stakeholders joined Alpha. The board of directors got new members too. Among them was the current CEO, who also has his educational background in chemistry. A few strategic decisions were made. First, Alpha decided to start working in a complementary product segment (floor maintenance equipment). A few European machinery manufacturers, fitting Alpha's criteria, were identified, and Alpha started importing a few pieces of equipment first from the UK and later from France with the intention to export them to their customers as a complementary solution for floor maintenance. Second, along with the growth of international operations, a spin-off trading firm was established by bringing in one more stakeholder (family outsider) to the entrepreneurial team. Despite these changes, Alpha still manages part of its international sales (mainly to its devoted customers) without assistance of the established trading firm. The products are being sold either under their own brand or under brands of the customers.

Regular participation in international trade shows, aimed at finding new prospects as well as maintaining relationships with current customers, resulted in the firm better understanding what kind of opportunities exist, where they exist and how scalable and realistic they are:

We have understood that there was much more to do with the stone, in France, Italy and Spain.

We have had a lot of contacts with our prospects in Croatia, sent samples of our product to them, but not much has happened there yet... But we still continue working with Croatia, also with Poland, Bosnia and Turkey. For example, we established quite good relationships with Turkey, but costs of delivery... Well, product delivery down there seems to be quite problematic now.

Our primary focus was on Europe, and our ambition was to expand to European countries, but via trade shows we have established contacts with other customers 
from other parts of the world. We have established very good relationships with Dubai, and we realised that it is a very promising market for us.

Working with foreign prospects and existing customers also led to increasing the firm's understanding of national and business culture in the markets where the firm tried to establish their operations. This increased understanding of cultural aspects of business operations overseas was considered to be valuable for product adaptation:

The mentality of our customers in different markets differs a lot. While our customers in some markets are not so strict with regard to, let us say, how the product packaging would look and often simply accept our suggestions, it is completely different for our customers in other markets. A communication process can be much longer, and we might be required to negotiate every detail on the packaging: how large the label should be, which font size should be used on the label, how large certain symbols should be and where exactly on the label they should be positioned.

The interviewed owner-manager at Alpha was also aware about opportunities in the border market (Norway), and having established direct contacts with end customers, exported the products to this market too. However, because of customs regulations, as well as customs duties, time and costs of customs procedures, operations in Norway, which were of a relatively low volume, were considered resource demanding, which resulted in leaving this market.

When extending its networks Alpha relies mostly on trade shows and considers personal contacts the most important:

There [at trade shows] we meet people, we talk to them and we try to build trust between us and them.

It is highlighted that personal meetings with representatives of those firms and organisations, with which Alpha does not have and/or intend to have any transactions (e.g. other industrial companies operating in other industries, municipalities, universities, etc.), are also of great importance to them:

When we meet, it is always good to talk about others' experiences: what was good, what worked well... As a result of these meetings we understand, OK, this would be good to do together with $\mathrm{X}$, or that is something we have to think about when we make a similar thing.

Firm Beta was founded in Norway in 1995 by an ambitious young entrepreneur with an educational background in information technologies. The entrepreneurial idea was built around the computer design and manufacturing of interior elements of a solid-surface material. Beta did not aim at international expansion from its inception and instead was focused on establishing a strong position in the domestic market. Choosing to operate in the business-to-business (B2B) segment, while the business-to-consumer (B2C) segment was also a potential alternative, and offering its customers tailor-made, inhouse designed (often co-designed together with its customers) and manufactured 
products of premium quality, the firm aspired to respond to their customers' needs in order to earn a solid reputation, which the firm could capitalise on in the future:

What is interesting about us is that we have not been good at marketing ourselves... We have not been so good at building our visibility online or using Google optimisation... We did not work with social media at all because for us it was a tool that was not much associated with $\mathrm{B} 2 \mathrm{~B}$, and in the beginning we chose to abstain from that since we did not want to have B2C. We did not do anything internationally in the beginning. What helped us the most is actually 'jungle telegraph', I mean previous projects, which we did for our customers and put a lot of effort into. For us, it always starts with someone seeing our products and then getting in touch with someone in their network. That works!

Although a gradually acquired reputation helped the firm to both gain new domestic customers and grow together with the returning ones, it was decided to develop an alternative route-to-market focusing on establishing relationships with middlemen (interior designers and architects) who would be able to recommend the firm's products to end users:

We decided to map all the interior designers in this country, both large and small, and then we selected a smaller sample using a number of criteria (including the size) of those potential partners, whom we chose to introduce ourselves to, so we went straight to them. But it was a bit divided, we realised that there were many others who were contacting the interior designers, but they often wanted to have just one partner to have strong relationships with. It is not common that an interior designer wants to buy for example Corian from us and woodwork from someone else. So it made us think in terms of developing 'packages' for our potential partners, and it means we may need to dare to have more breadth and more skills for several types of materials. I think we can get more orders and grow faster than we do now just with Corian and Plexiglas acrylic we are good at.

While not seeking opportunities overseas, Beta managed to get occasional orders from new customers from Great Britain almost two decades after the firm's inception. These new customers were a part of Beta's former customers' international business networks, and the word-of-mouth generated by former customers as well as the product quality, which 'spoke for itself', contributed to the firms' international customer base expansion:

We have some customers overseas, and we have mostly dealt with the interior design for various TV productions. Our first British customer was X, which is a TV channel. The main reason why they approached us and afterwards we got our first order from them is that we are the main supplier to $\mathrm{Y}$, a Norwegian TV channel. $\mathrm{Y}$ is considered to be very good at designing their studios for different programs, so they received a number of inquiries from other TV companies, not only in Norway but also abroad. Basically, it was Y who promoted us and it all started in this way. 
Later Beta was also approached by its other customers' international partners, and although there were lucrative opportunities identified in Italy and the Netherlands, they were never pursued:

We also produce merchandising displays, we design and manufacture a lot of displays for globally renowned brands, but mainly for their points of purchase in Norway. Usually it's the wholesalers here in Norway who choose our displays, as they generate more sales to them compared to other displays, which often look a little bit boring. That is why wholesalers are inclined to put some more money into displays. I asked: 'Why not use similar displays in the rest of Europe?' and we actually got a visit from Italy (brand A), they looked at our displays, and we received very good feedback. Then we got a visit from the Netherlands (brand B), and they liked our displays too. However, both logistics and costs were not optimal for them, so it did not result in anything.

Having learned from its experience with both pursued and non-pursued international opportunities, Beta started considering its international expansion an alternative for further development. Nordic markets, which the firm had some understanding of, were perceived to demand less effort to penetrate than other markets, being perceived as less familiar. To optimise the cost structure for international operations, it was decided to initiate an overseas production jointly with a partner in a European country with a lower level of production costs than in Norway:

Now we have also found a partner in Latvia, they will manufacture products designed by us for our European customers. This solution should cut total costs for our European customers. We have realised from our previous experience that as soon as the cost issue pops up in the process of negotiations, we are no longer on track.

The importance of personal contacts with local partners in general, and local customers in particular, is highlighted for the firm's internationalisation:

There are other types of formal contractual arrangements in this industry. It's not like what I was used to before. Actually, I come from a completely different industry, from the electronics industry, where I used to bind myself by contract. It does not work here, in this industry, in the same way. It is possible to enter into a contract for delivery of storable products on a regular basis, however, it is almost impossible to enter into an agreement for becoming an exclusive supplier. For us it would mean to deliver everything - from design to installation. Instead we have a lot of one-time orders, and most of them are quite unique. Can you imagine, most of our products are not standardized, like a reception desk, a table for a TV studio or a display for a well-known brand? They should look special, and it's not often that our customers have to order such products again. In practice, it means that you need to sit down together with your customer to design, for example, a display and try to agree on a huge number of details. To come to an agreement 
you have to have a good dialogue with the customer, and good personal contacts are important. This is quite an old way to work - to visit your customers, to sit down with them, to talk to them. These personal meetings work best.

We are members of an industrial association here in town, but I have to admit we are quite a passive member. Then we are a part of the cluster... It's interesting to hear from others how they do things, what problems they have, it's almost more interesting than hearing about what's happening in our own industry. It is interesting to learn from other industries.

Firm Gamma was established in Norway in 1987 by two young mechanics with a technical background and some employment experience in machine service and maintenance. The entrepreneurs were seeking to provide machining services to local industrial firms. With the vision to increase their customers' productivity, their own small-scale manufacturing of prototypes and machine components was initiated almost from the outset.

The entrepreneurs first started considering a cross-border expansion about 20 years after the firm inception. The interviewee, one of the firm founders and the principal owner, could not clearly explain why they started thinking about searching for international opportunities:

We wanted to try to do something outside Norway. I do not know why. We had a feeling that we were grown up enough for this step.

The border market seemed to be quite familiar, and the firm founder-managers had some understanding of the industry structure in the region, which is why they considered establishing contact with a few prospects in Sweden:

We are located quite near the Norwegian-Swedish border, and we knew that on the other side of the border there were some companies that might be interested in what we do. So I made a call to one of them, and we agreed on a meeting at their site. While there were no more than $80 \mathrm{~km}$ between us, we had never been in touch before. So we drove there to introduce ourselves. We wanted to indicate we are here, we are not far away and we can deliver this and that.

While this active approach to establish operations in the border market only resulted in one-time, sporadic orders from Swedish customers, the firm was able to identify a number of positive outcomes from this experience:

It was not a big success. We started getting orders from Sweden now and then. At the same time there were a lot of positive things around that. First, we learnt a lot from our Swedish customers, about their needs, their expectations... In general we got a better understanding of the Swedish market. Then we realised what we are worth, that our efforts to achieve technical excellence have actually resulted in something. We got a good reputation in Sweden, people got to know who we are.

A few years after having started to actively search for opportunities in the border market, Gamma was approached by a domestic subsidiary of a large Swedish multinational offering a partnership agreement: 
They realised that we had the same type of customers, often the same customers, but we served different needs. So they wanted us to be a partner and to serve all their customers. Consequently we expanded internationally together with our customers.

New opportunities in Eastern Europe were discovered via personal contacts of one of the founder-managers of the firm.

I met this guy here, in the city. Originally, he comes from Lithuania, but he had already lived in Norway for more than five years by the time we met. In our small place we do not have a lot of people from Eastern Europe, so it was interesting to talk to him. About different things at first, then about business. He was friendly, trustful and knowledgeable. So, we started thinking about moving a part of our production to Eastern Europe.

After joint evaluation of a number of opportunities in the countries of Eastern Europe, Gamma decided to enter into partnerships with a few actors in Poland and partially moved its production to Poland, which enabled it to optimise its production cost structure. This decision enabled Gamma to serve customers in other countries of the region.

Firm Delta was founded in Sweden in 1994 by two engineers with a few years of employment experience as industrial machinery developers. Since then, Delta had served the needs of the industry in the regional domestic market and had no ambitions to internationalise. Internationalisation of Delta started accidentally:

It started by coincidence. We did not think about serving foreign customers. We just designed and manufactured machines, different pieces of equipment and tools for various industrial companies in the region.

Approximately seven years after its inception, Delta was contacted by a representative of an intermediary firm wanting to buy a piece of machinery. Although the firm had not had any previous contacts with this agent, the deal was successfully completed the same year. However, establishing and developing relationships with this intermediary resulted in a number of changes. Being in constant contact with end users in the industry and being familiar with their needs, the intermediary's representative was able to identify a potential niche, which Delta would be able to fill. After having changed the ownership structure by bringing in a new owner (the previously mentioned representative of the intermediary), the firm started developing a new product aimed at reaching solely foreign customers in a new (for the firm) industry segment. New product development took a few years, and all the developed technical solutions were patented in Sweden, Norway, the EU and USA. Since the new product launch, the firm started expand internationally:

Then, in 2006, we ended up in the international market directly. First, we started to deliver to Norway, then it just moved forward. After five years our international sales generated most of our revenues. This is the balance we still have. We have some single customers from Sweden, but the majority are foreign. 
After the initial launch of the product to a geographically and institutionally proximate market, Delta started actively looking for business opportunities abroad. An extensive global market research was initiated, and Delta began creating a marketing information system, carefully mapping identified prospects worldwide. At this stage, Delta cooperated actively with institutional actors in the region, such as a regional university, entrepreneurship support organisation and employment agencies, offering internships to those who were interested in conducting desk market research for the firm.

While Delta managed to reach their customers in both geographically proximate (Norway, Denmark, Germany, the Netherlands, UK) and distant markets (USA, Australia, Mexico), the border market (Norway) has become dominant. Extending its business network internationally, the firm established strategic relationships with a sales agent in Norway aiming at complementing its direct sales to its foreign customers with indirect export. The sale agent got exclusive rights to sell the firm's products to both Norwegian and other foreign customers:

Basically, we wanted to have someone who'd take care of processing our new customers. It was the main point to have this sales agent. We have a kind of gentleman's agreement with them. We take care of production and further product development, and they take charge of marketing and sales.

While, in general, Delta was quite satisfied with how the relationship with the exclusive sales agents functioned, as well as with the level of trust between partners, the interviewee also expressed some minor reservations about the sales performance:

It goes quite well. They sell of course, but maybe not to the extent we'd like them to do. We sell to the whole world via Norway, but we can do more... We can increase our production capacity tenfold, we need another channel to sell even more...

Having realised that there were numerous international opportunities to pursue, Delta made attempts to 'materialise' these opportunities, i.e. to make them more concrete and 'tangible':

We take part in trade shows regularly (three-four times a year), we do extensive market research, we talk with Business Sweden, we try to establish contacts with our prospects, and we try to present ourselves to them. Trade shows seem to be the most important for us, there we have good chances to establish new as well as maintain current relationships with prospects, customers and potential agents.

The importance of personal meetings is often highlighted in the process of relationship development:

We visit them [partners] often, and they come here often too. Actually, some visit us very often, it could be like every two months, others less often. But these visits and personal contacts, they generate so much for us. We share our experiences, 
discuss our problems, and try to find solutions. We observe that after these meetings things start happening, we have another dynamic.

\section{Cross-case analysis and discussion}

Our case findings suggest that the focal firms identify their international opportunities by both discovery and creation (see Fig. 2).

\section{Identification of primary international opportunities}

\section{By means of discovery}

Identification of primary international opportunities by two (Beta and Delta) out of the four focal firms can be seen as the result of a discovery process rather than creation (see Table 5). This is quite expected taking into consideration that the entrepreneurial managers of these firms had no prior internationalisation knowledge (Eriksson et al. 2000) at the time of the first international opportunity discovery, which is consistent with previous research results obtained for early internationalising firms operating in high-technology industries (Crick and Spence 2005; Chandra et al. 2009) as well as late internationalising firms in traditional industries (Kontinen and Ojala 2011a, b; Masiello and Izzo 2019).

International opportunity discoveries in Beta and Delta seem to be the result of the entrepreneurs' opportunistic behaviour in response to 'serendipitous encounters' (Crick and Spence 2005), which have occurred in the firms' business networks, mostly consisting of domestic customers and suppliers, with whom the firms have regular,

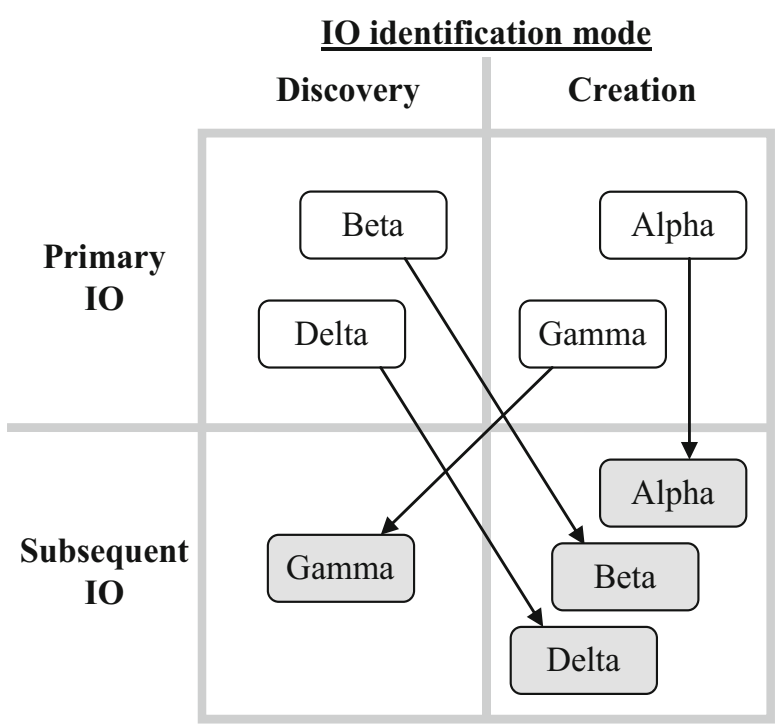

Fig. 2 Modes of international opportunity (IO) identification by focal firms 


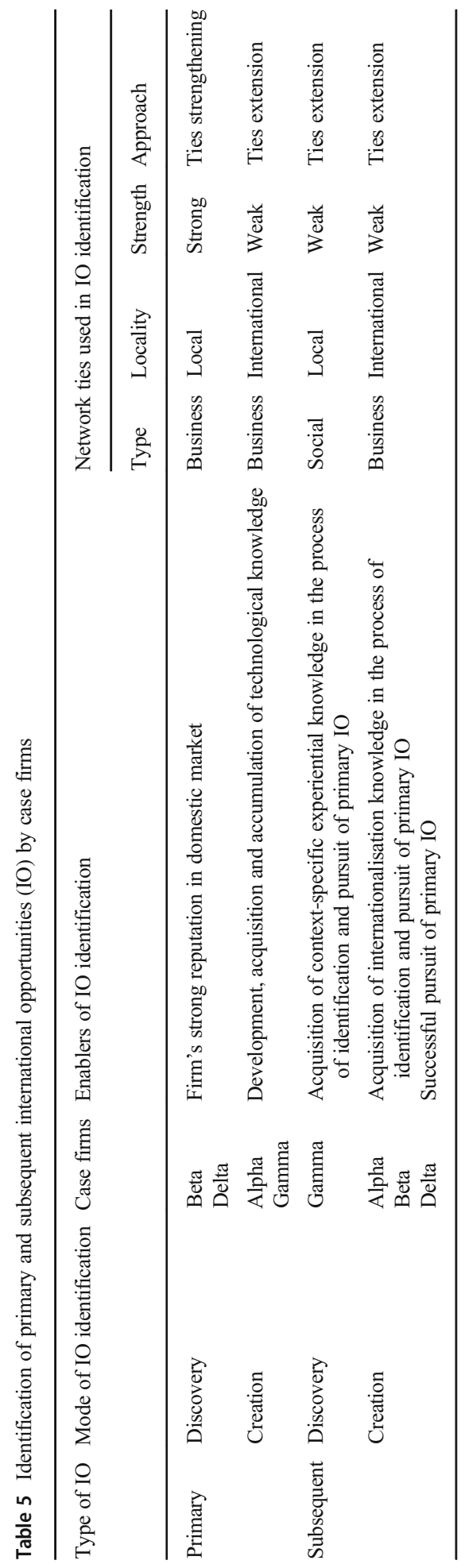


intense relationships based on mutual trust and commitment (which we classify as strong ties). Although serendipitous discoveries of opportunities are often considered to be pure luck (Ellis 2000; Vasilchenko and Morrish 2011), we concur with Chandra et al. (2009) that opportunity discovery should be distinguished from pure luck. Chandra et al. (2009) view international opportunity discovery as a result of firms' network utilisation, competencies and motivations. Drawing on the findings of Goldberg et al. (2003), who argue that the development of firms' core competencies is one of the most effective strategies to enhance firms' reputation, we support Chandra et al.'s (2009) view and suggest that identification of international opportunities by mature firms in medium-technology industries by means of discovery can be explained by their established reputation in their domestic markets. A firm's reputation, which is essentially a perceptual representation of the firm's past actions (Fombrun 1996), is important for the firm's exchange partners, especially customers (Reuber and Fischer 2005) because it serves as an indicator of the firm's ability to produce valuable outcomes for them in the future (Fombrun et al. 2000). Hormiga and García-Almeida (2016), based on their study of low- and medium-technology firms, find that customer perceptions of the firm contribute to the firm's growth as well as other positive outcomes (e.g. extension of the firm's customer base). As a result, the firm extends the number of its business ties, which, in turn, is likely to increase its international exposure and provide it with more international opportunities (Fernhaber and Li 2013). We therefore suggest that small mature firms in medium-technology industries, having a strong reputation in the domestic markets, are likely to discover their primary international opportunities via their business networks.

Although the role of business networks in identification of international opportunities is highlighted by international entrepreneurship research (Andersson 2004; Mainela et al. 2014), they are largely considered to be of importance for high-technology firms, which are likely to internationalise early (Coviello and Munro 1995; Presutti et al. 2007; Blankenburg Holm et al. 2015). Relying on strong ties in international opportunity identification contradicts the results previously obtained for late internationalising firms in traditional industries (Kontinen and Ojala 2011a; Zaefarian et al. 2016). Supporting the view of Oyson and Whittaker (2015) on context specificity of the international opportunity discovery mode, our observations suggest that dependence of mature firms in mature industries on strong business ties in their discovery of primary international opportunities could be accounted for by the context of the industry they operate in, and, consequently, the type of product they offer to the market. The market offer of a medium-technology firm can be the outcome of either mass, small series or one-of-a-kind production (Hvam et al. 2008). Firms involved in small series and oneof-a-kind production, in order to better meet their customers' expectations, often need to customise their products, i.e. tailor them to a specific customer's requirements (Hvam et al. 2008). The process of product customisation necessarily requires at least some degree of customer involvement in product development (Du et al. 2006). Based on the cases of Beta and Delta, we observe that the firm's high needs for product customisation, and consequently high levels of customer involvement in product development, have resulted in development of more frequent, intimate and in-depth interactions with their customers, i.e. strengthening their business ties. Drawing on the considerations above, we suggest that small mature firms in mature industries with high needs for product customisation and/or customer involvement in product development 
are likely to identify their primary international opportunities (i) by means of discovery, and (ii) by strengthening their existing business ties. These findings, however, contradict to those of Magnani and Zucchella (2019), pointing towards (i) the adoption of a proactive approach in internationalisation by such firms, and (ii) their self-sufficiency in this process (i.e. non-dependence on their networks). Such an incongruence in the reported findings can be explained by different approaches to case selection (a smaller vs. larger sample size, focus on a narrow vs. broader range of firm types; industries with the same vs. various levels of knowledge intensity), as well as different national settings (Scandinavia and Italy are characterised by a number of political, economic, social and cultural dissimilarities).

\section{By means of creation}

The other two studied firms (Alpha and Gamma) created their international opportunities in both geographically and institutionally proximate (Gamma) and distant (Alpha) markets by active and deliberate search (Table 5). Taking into consideration that neither of these two firms possessed any prior internationalisation knowledge (Eriksson et al. 2000), this finding is quite surprising since it is not in line with our expectations based on the previous research results (Chandra et al. 2009; Kontinen and Ojala 2011a; Bai and Johanson 2018). The evidence from Alpha and Gamma indicates that their creation of international opportunities seems to have been enabled by development, acquisition and accumulation of technological knowledge within the process of new product development (Fletcher and Harris 2012). Although the accumulated technological knowledge differs substantially with respect to the degree of its novelty between these two cases (a radically new formula for the floor detergent in the case of Alpha and application of existing technologies for product modifications in the case of Gamma), it seems to have prompted the firms to realise that their products are likely to be competitive outside the domestic markets and that they themselves are 'grown up enough' to make a step towards foreign markets. Thus, in terms of Oyson and Whittaker (2015), technological knowledge development facilitated the focal firms in cognitively bringing together all three entrepreneurial opportunity elements (product, customer and possibilities) that constitute a purposive process of international opportunity creation (Oyson and Whittaker 2015). Following this reasoning, we suggest that mature firms in medium-technology industries, after having accumulated necessary technological knowledge, are likely to start the identification of international opportunities by means of creation. Thus, such firms might become more similar to hightechnology firms in terms of speed of internationalisation, for which technological knowledge is considered to be an important driver of rapid internationalisation (Oviatt and McDougall 2005).

In contrast to Beta and Delta, which in their primary international opportunity discovery relied on local business networks with strong ties, Alpha and Gamma in their primary international opportunity creation utilised their international business networks with rather weak ties and made every attempt to extend their business networks by establishing new relationships (often via international trade shows). Thus, our findings support the results of previous studies highlighting the importance of trade shows in the extension of business networks by mature firms in mature industries and, 
subsequently, the identification of international opportunities (Evers and Knight 2008; Evers and O'Gorman 2011; Zaefarian et al. 2016).

While the international entrepreneurship literature highlights the importance of weak ties for international opportunity identification (Chandra et al. 2009; Kontinen and Ojala 2011a; Zaefarian et al. 2016), they are expected to be utilised by those firms that are involved in international opportunity identification by discovery rather than by creation (Chandra et al. 2009; Masiello and Izzo 2019). We try to account for this idiosyncrasy by drawing on Reuber et al.'s (2017) claim on the importance of industry context for generating explanations about variations in firms' international opportunity identification. Contrasting the evidence obtained from Alpha and Gamma to that attained from Beta and Delta with respect to their needs in their product customisation and/or customer involvement in product development, we suggest that mature firms in mature industries with low need for product customisation and/or customer involvement in product development are likely to identify their primary international opportunities (i) by means of creation, and (ii) extending their business networks, i.e. by creating new business ties.

Hence, by establishing this link, we extend the findings of Hennart (2014, p. 129) who contends that a firm's business model, namely 'the way they have linked the type of product or service they sell with a particular subgroup of customers' determines the firm's international behaviour. Hennart (2014) posits that firms with low product adaptation costs tend to internationalise faster than those with higher adaptation costs. Our findings point out that firms with lower need (and consequently costs) for product customisation (which implies the adaptation of the product to a certain customer's needs) tend to be more proactive than reactive in the process of their primary international opportunity identification.

While all focal firms at the time the study was conducted were embedded in different types of networks (local and international, business, social and institutional), we find no support for the utilisation by the studied firms of either institutional or social networks in the process of primary international opportunity identification. In this respect, our findings differ from those having articulated the triggering function of social (Ellis 2011; Evers and O'Gorman 2011) and institutional ties (BelsoMartínez 2006; Kontinen and Ojala 2011a; Oparaocha 2015) in international opportunity identification.

\section{Identification of subsequent international opportunities}

All focal firms have managed to exploit their primary international opportunities, which they have identified. When it comes to the identification of subsequent international opportunities, only one out of the four studied firms (Alpha) favoured the same approach that was employed during the identification of primary international opportunities (creation). Two out of the four focal firms (Beta and Delta) went from discovery to creation, and one (Gamma) from creation to discovery (see Fig. 2).

Favouring the creation mode in subsequent international opportunity identification by three of the four studied firms is quite predictable due to an increase in internationalisation knowledge and experience, which they acquired in the process of primary international opportunity identification (Johanson and Vahlne 2009; Chandra et al. 2012; Chetty et al. 2018). Along with the acquisition of 
internationalisation knowledge and experience as well as extension of their business networks by creating new ties, three of the studied firms (Alpha, Beta, Delta) became more proactive in subsequent opportunity identification compared to primary international opportunity identification. These observations are in line with Chetty et al. (2018), who suggest that networking capabilities are required when firms move either from discovery to creation or from creation to discovery in subsequent international opportunity identification.

Furthermore, successful exploitation of primary international opportunities seems to contribute as well to adoption by the studied firms of a more proactive approach (creation) in subsequent international opportunity identification (Chandra et al. 2012), which is likely to be followed by a growth in the firms' strategic orientation (Venkatraman 1989). Hence, we support the claim of Reuber et al. (2017) who state that the outcomes of the identification of one opportunity may become the antecedents of the identification and pursuit of subsequent opportunities. Our case evidence also suggests that proactiveness in the process of creation of subsequent international opportunities is mediated by the reassurance that the entrepreneurs get when their firms have successfully pursued primary international opportunities. Reassurance contributes to a higher level of self-efficacy, which has an important role in shaping perseverance (Ardichvili et al. 2003; Chen et al. 2004). While creating subsequent international opportunities the focal firms continue to rely on their business networks, they are predominantly focused on their extension by creating new international ties. This finding is partially inconsistent with the observations of Evers and O'Gorman (2011), who report that internationalising small firms in mature industries become more dependent on existing business ties as they move to new markets.

One out of the four focal firms (Gamma) moved from a proactive creation of the first international opportunity via its business ties to a reactive discovery of subsequent international opportunities via the firm's manager's new social ties. Such a move can be explained by the requirements of 'additional ingredients' (Chetty et al. 2018) in primary opportunities, such as accumulation of context-specific experiential knowledge, which helps entrepreneurs to develop certain 'cognitive frameworks' (Baron 2006). These frameworks, in turn, enable entrepreneurs to perceive seemingly unrelated connections between different events, trends and environments as well as efficiently interpret and reflect over acquired context-specific knowledge (Baron 2006). Consequently, development of cognitive frameworks as a result of acquisition of context-specific knowledge can lead to higher entrepreneurial alertness (Baron 2006) and, accordingly, development of entrepreneurial capabilities, which are needed to generate opportunity discovery (Chetty et al. 2018).

Three out of the four studied firms (Alpha, Beta and Delta), after having successfully exploited their primary international opportunities, identified several subsequent international opportunities they never managed to pursue for various reasons (such as lack of internationalisation knowledge in the case of all three firms; environmental constraints in the case of Alpha in Turkey or resource scarcity in the case of Beta). Similar to the findings reported by Chetty et al. (2018) for high-technology firms and Chandra et al. (2012) for firms operating in a wide range of industries, the studied firms in mature industries perceive their non-pursued ('false' in terms of Chandra et al. 2012) international opportunities as a beneficial learning experience, which contributed to identification of other subsequent opportunities. Furthermore, our case evidence suggests that 'false' international opportunities function as triggers for the entrepreneurs to 
(i) realise the urgency of needed strategic changes (such as in the case of Beta, which having reflected upon their failure experience, decided to move part of their production to Latvia), and (ii) identify future learning content, i.e. knowledge that should be acquired by the firm for successful international expansion.

\section{Conclusion}

The study sought to gain a better understanding of how small late internationalising (mature) firms operating in mature industry contexts (medium-technology industries) identify primary and subsequent international opportunities. Earlier international entrepreneurship research, while not favouring mature firms in mature industries, reports inconsistent findings for them with respect to identification of primary and subsequent international opportunities by discovery versus creation as well as use of various types of networks in these processes.

Having integrated international opportunity (Mainela et al. 2014, 2018; Chetty et al. 2018; Reuber et al. 2017, 2018) and network literature (Coviello and Munro 1995; Chetty and Blankenburg-Holm 2000) as well as employed a multiple case study design (Yin 2014) to investigate identification of primary and subsequent international opportunities by small mature firms operating in mature industries, we make several contributions.

First, our findings advance the growing body of knowledge on the importance of networks in identification of both primary and subsequent international opportunities by small late internationalising firms operating in mature industries (Kontinen and Ojala 2011a; Veglio and Zucchella 2015; Francioni et al. 2017; Masiello and Izzo 2019). Specifically, using network characteristics (type, strength, locality and development of ties), we provide insights to variations in international opportunity identification by these firms, thus contributing to theoretical advances in international opportunities. Concurring with Chandra et al. (2009), we view discovery of primary international opportunities as the result of the role of networks, firm competencies and motivation. Further, highlighting the value of strong business ties in this process, we explain primary international opportunity discovery by established reputation of the firm in the domestic market, which facilitates the extension of the firm's business ties, which, in turn, is likely to increase its international exposure and provide it with more international opportunities (Fernhaber and Li 2013). Building on Oyson and Whittaker (2015), who see the creation of international opportunities by firms as a purposive process, where they have to cognitively integrate all three elements of entrepreneurial opportunities (product, customer and possibilities), we find that development, acquisition and accumulation of technological knowledge (Fletcher and Harris 2012) prompts mature firms in mature industries to identify their primary international opportunities by means of creation and highpoint the strengthening of business ties in this process (Kontinen and Ojala 2011a).

Second, recognising the importance of industry context in generating explanations for variations in firms' international opportunity identification (Reuber et al. 2017), and through the bridge with international business studies (Hennart 2014; Magnani and Zucchella 2019), we suggest that for mature firms in mature industries, the type of product these firms offer to the market (low versus high need for customisation and/or customer involvement in product development) has a potential to provide valuable explanations of the firms' international behaviour. 
Third, responding to the calls for more studies aimed at advancing our understanding of linkages between primary and subsequent opportunity as well as opportunity discovery and creation (Chandra et al. 2015; Chetty et al. 2018), we provide useful insights on how late internationalising firms in mature industries move from first-time to subsequent international opportunities utilising their networks. We show that maintained proactiveness in the process of creation of subsequent international opportunities is mediated by the reassurance (Ardichvili et al. 2003; Chen et al. 2004) that the entrepreneurs get when their firms have successfully pursued primary international opportunities. Further, we extend the understanding of the shift from a proactive creation of the first international opportunity to a reactive discovery of the subsequent opportunities by highlighting the importance of context-specific experiential knowledge, triggering development of 'cognitive frameworks' (Baron 2006) by entrepreneurs, and, subsequently, their entrepreneurial alertness (Baron 2006).

Finally, we contribute to international opportunity literature by establishing more clarity on the role of non-pursued opportunities (Chandra et al. 2012; Chetty et al. 2018) in the subsequent international opportunity identification.

\section{Managerial implications}

This research generates implications for managers of small firms operating in mature industries that have ambitions for international expansion. Since business networks seem to play a crucial role for these firms in both primary and subsequent international opportunity identification, managers can be advised to invest resources in networking activities with other business actors (both domestic and international). Two alternative approaches for business networking are plausible. For the firms whose products do not require high levels of product customisation and/or customer involvement in product development, it could be recommended to focus on business network extension, i.e. to create new business relationships by, for example, attending international trade shows. For firms not falling in the first category, strengthening of ties with existing business partners could be considered a preferred networking strategy.

\section{Policy implications}

For policy-makers and entrepreneurship support organisations aimed at encouraging mature firms to internationalise, it is important to recognise that business networks have a crucial role in identification of primary international opportunities. Thus, export support programs targeted at small mature firms in mature industries should provide financial and non-financial assistance to these firms to facilitate their business networking both locally and internationally.

\section{Limitations and further research}

Our study has some limitations that we would like to explicitly acknowledge. First, our study is based on a small sample of mature firms originating from two countries and belonging to different mature industries (nonetheless with the same level of knowledge intensity), which constrains the generalisation of the findings of this research. 
Therefore, it would be of interest to formulate hypotheses based on our findings (especially those applying to the association between product type and mode of international opportunity identification) and test them on a larger sample of small firms. In this case, it would be advisable to consider various mature industries and national contexts. This would enable researchers to verify if the findings are consistent or if they depend on the chosen methodology and sample.

Second, memory recall bias of the interviewees can be considered a challenge to the research results because the interviews covered the firms' past international behaviours stretching at least 20 years back in time. Accordingly, to minimise memory recall bias, future research should focus on mature firms which start to internationalise relatively earlier, i.e. 6 to 10 years after their inception, or/and adopt longitudinal approaches.

Acknowledgements The authors thank editor-in-chief Hamid Etemad and two anonymous reviewers for their valuable comments on earlier versions of this work.

Author contributions Nataliya Galan is the lead author responsible for carrying out the entire study, which Ellinor Torsein contributed to. The authors confirm their contributions to this article as follows: study conception: both authors; study design: Nataliya Galan; data collection, data analysis: both authors; results interpretation, writing and revision of manuscript: Nataliya Galan. Both authors reviewed and approved the final version of the manuscript.

Funding information Open access funding provided by University West. This study received financial support from the InterReg project (No. 20200960) funded by European Regional Development Fund.

\section{Appendix}

Table 6 Identification of primary and subsequent IO by case firms: key illustrative events, selected supporting quotes and related findings

\begin{tabular}{|c|c|c|c|}
\hline $\begin{array}{l}\text { Case } \\
\text { firm }\end{array}$ & Type of IO & $\begin{array}{l}\text { Key illustrative events } \\
\text { and selected supporting quotes }\end{array}$ & Related findings \\
\hline \multirow[t]{2}{*}{ Alpha } & Primary & $\begin{array}{l}\text { - R\&D collaboration with a medical } \\
\text { research firm for the purpose of a new } \\
\text { product development. } \\
\text { - Development of a new formula for the } \\
\text { core product, which Alpha identified } \\
\text { later its primary IO with. }\end{array}$ & $\begin{array}{l}\text { Development, acquisition and } \\
\text { accumulation of technological } \\
\text { knowledge, needed for a new product } \\
\text { development, enabled identification of } \\
\text { primary IO. }\end{array}$ \\
\hline & & $\begin{array}{l}\text { - Sensing a foreign market potential for } \\
\text { the core product and undertaking } \\
\text { deliberate actions (participation in trade } \\
\text { shows) in order to identify primary IO: } \\
\text { '[...] we got a feeling that there were good } \\
\text { market opportunities outside Sweden. } \\
\text { There are many more stone floor } \\
\text { manufactures abroad than in Sweden, } \\
\text { like in Italy, France, Spain... }\end{array}$ & $\begin{array}{l}\text { - Primary IO was identified via creation. } \\
\text { - Reliance on international business } \\
\text { networks with weak ties in primary IO } \\
\text { identification. } \\
\text { - Primary IO was identified via extension } \\
\text { of firm's business ties abroad. }\end{array}$ \\
\hline
\end{tabular}


Table 6 (continued)

\begin{tabular}{|c|c|c|c|}
\hline $\begin{array}{l}\text { Case } \\
\text { firm }\end{array}$ & Type of IO & $\begin{array}{l}\text { Key illustrative events } \\
\text { and selected supporting quotes }\end{array}$ & Related findings \\
\hline
\end{tabular}

So we decided to search for customers via relevant trade shows'.

- Appraisal of operations capabilities for international expansion:

'Basically, our production is quite a plain process which consists of mixing up a number of "ingredients" and can be run by very few employees no matter how much we plan to produce. Then, it is costly for us to find a foreign customer (in terms of time and costs of participating in exhibitions) but after that we do not have to do much, the product would speak for itself. The only thing that we have to do is to agree with our customer about product pre-packaging. Basically, we need to know two things: whether our customer would prefer larger or smaller containers, and whether they would sell it under our product name or their own. The latter is fine for us but we have to adjust the label'.

Subsequent - Evaluation of benefits related to attending the first trade show.

- Regular attendance of trade shows with twofold objectives - to establish new contacts and to maintain the existing ones:

'Exhibitions and trade shows are extremely important to us as we operate in such a traditional industry. Yes, they are quite expensive if we count participation fees, transport expenses, travel and accommodation expenses. However, we get back quite a lot, too. Only there we get a very good chance to be seen by others, to meet our potential customers, to sit and talk to them. Of course, in our age of digital technologies, Skype and email might work too, but it is not the same'.

'Our primary focus was on Europe, and our ambition was to expand to European countries, but via trade shows we have established contacts with other customers from other parts of the world. We have established very good relationships with Dubai, and we realised that it is a very promising market for us'.
- Low needs for product customisation.

- Low level of customer involvement in product development/customisation.

- Favourable experience with primary IO is likely to have had an encouraging effect on the firm's ambition to look for subsequent IO.

- Subsequent IO were identified via creation.

- Reliance on international business networks with weak ties in subsequent IO identification.

- Subsequent IO were identified via extension of firm's business ties abroad.

- 'False' opportunity contributes to acquiring more knowledge about foreign markets as well as indicates what changes should be made. 
Table 6 (continued)

\begin{tabular}{|c|c|c|c|}
\hline $\begin{array}{l}\text { Case } \\
\text { firm }\end{array}$ & Type of IO & $\begin{array}{l}\text { Key illustrative events } \\
\text { and selected supporting quotes }\end{array}$ & Related findings \\
\hline
\end{tabular}

- Establishing a spin-off trading company after having experienced a growth in international operations.

- Assessment of feasibility of subsequent IO:

'We know that Turkey would be a fantastic opportunity for us. We have also established some contacts with potential Turkish customers. However, for us, the situation there seems to be risky, and we do not fully understand what is going on there right now. We feel that we cannot have full control over the situation there. We try to follow up the situation, and I think we should be better in monitoring political situation in other countries, where we export to, too, but it is a bit difficult, as we are too small. We tried to find a way to this market, and we are thinking about finding an intermediary in another non-EU country with fewer risks, who would be able to take care about distributing our product in the region'.

- A strategic decision to operate in B2B segment in the domestic market:

'I did not have much experience when I started the firm, and there were no ambitions to go international. Besides I am coming from another industry, so we tried to serve both $\mathrm{B} 2 \mathrm{~B}$ and $\mathrm{B} 2 \mathrm{C}$ segments. However, we realised soon that it was not possible, since we offer our customers tailor-made solutions, and we often need to sit down and work closely with them in order to better understand their wants. As a small-scale manufacturer we were not able to serve many customers, so, we decided to focus on just B2B'.

'Can you imagine, most of our products are not standardized, like a reception desk, a table for a TV studio or a display for a well-known brand? They should look special, and it's not often that our customers have to order such products again. In practice, it means that you need to sit down together with your customer to design, for example, a display and try to agree on a huge number of details. To come to an agreement you have to have a good dialogue with the customer, and good
- High needs for product customisation.

- High level of customer involvement in product development/customisation. 
Table 6 (continued)

\begin{tabular}{|c|c|c|c|}
\hline $\begin{array}{l}\text { Case } \\
\text { firm }\end{array}$ & Type of IO & $\begin{array}{l}\text { Key illustrative events } \\
\text { and selected supporting quotes }\end{array}$ & Related findings \\
\hline
\end{tabular}

personal contacts are important. This is quite an old way to work - to visit your customers, to sit down with them, to talk to them. These personal meetings work best'.

- Focus on building a strong reputation in - Strong reputation and word-of-mouth in the domestic market:

'We did not do anything internationally in the beginning. What helped us the most is actually jungle telegraph, I mean the domestic market enabled identification of primary IO.

previous projects, which we did for our - Primary IO was identified via discovery. customers and put a lot of effort into. For us, it always starts with someone seeing our products and then getting in touch with someone in their network. That works!'

'It is always a challenge to get a customer, but it is also a bigger challenge to retain it due to peculiarities of the product we offer to them. That is why it is very important to us to work on our relationships and to be always close to our customers'.

'Our first British [foreign] customer was $\mathrm{X}$, which is a TV channel. The main reason why they approached us and afterwards we got our first order from them is that we are the main supplier to Y, a Norwegian [local] TV channel. Y is considered to be very good at designing their studios for different programs, so they received a number of inquiries from other TV companies, not only in Norway but also abroad. Basically, it was Y who promoted us and it all started in this way'.

Subsequent $\bullet$ Learning from earlier international experience:

'When we succeeded with our first order from abroad, we realised that we can offer something, which could be of interest to others not only here, in Norway, but in other countries of Europe, too. So, we started thinking about such opportunities'.

'Norway is probably the most expensive country in Europe, which means that we have very high production costs is we only have our production facilities here. After having been approached by potential foreign customers and negotiations with them, we realised that if we want our products to be

- Favourable experience with primary IO is likely to have had an encouraging effect on the firm's ambition to search for subsequent IO.

- International knowledge, acquired in the process of identification and pursuit of primary IO, enabled identification of subsequent IO.

- 'False' opportunity contributes indicates what strategic changes should be made.

- Subsequent IO were identified via creation.

- Reliance on international business networks with weak ties in subsequent IO identification. 
Table 6 (continued)

\begin{tabular}{|c|c|c|}
\hline $\begin{array}{l}\text { Case } \\
\text { firm }\end{array}$ & Type of IO & $\begin{array}{l}\text { Key illustrative events } \\
\text { and selected supporting quotes }\end{array}$ \\
\hline
\end{tabular}

Gamma Primary price-competitive in other European countries, we'd need a partner in Europe, who could manufacture our products, designed in Norway, in a country with lower production costs'.

'Now we have also found a partner in Latvia, they will manufacture products designed by us for our European customers. This solution should cut total costs for our European customers. We have realised from our previous experience that as soon as the cost issue pops up in the process of negotiations, we are no longer on track'.

- Long experience in the domestic market 'This part of Norway is very industrialised, and we have always known that local industrial firms need regularly machining services. We started serving these firms by providing them with these services, but we grew up with them and soon began to design and manufacture machine components for them. All our customers are from traditional industries, where things do not happen quickly. When we had learnt their technologies, we were able to exploit the results of our learning and benefit from large production volumes during some time. We tried to do our best to satisfy them, and we wanted to signal every local customer that they can rely on our expertise. So little by little we acquired their trust and confidence. They knew that we were capable to solve most of their technical problems in the shortest time possible'.

- Sensing a foreign market potential for the core product and undertaking deliberate actions in order to identify primary IO:

'We wanted to try to do something outside Norway. I do not know why. We had a feeling that we were grown up enough for this step'.

'We are located quite near the Norwegian-Swedish border, and we knew that on the other side of the border there were some companies that might be interested in what we do. So I made a call to one of them, and we agreed on a meeting at their site. While there were no more than $80 \mathrm{~km}$
- Subsequent IO were identified via extension of firm's business ties abroad.

- Low needs for product customisation.

- A low level of customer involvement in product development/customisation.

- Development, acquisition and accumulation of technological knowledge enabled identification of primary IO.

- Primary IO was identified via creation.

- Primary IO was identified via extension of firm's business ties abroad.

- Reliance on international business networks with weak ties in primary IO identification. 
Table 6 (continued)

\begin{tabular}{|c|c|c|c|}
\hline $\begin{array}{l}\text { Case } \\
\text { firm }\end{array}$ & Type of IO & $\begin{array}{l}\text { Key illustrative events } \\
\text { and selected supporting quotes }\end{array}$ & Related findings \\
\hline
\end{tabular}

between us, we had never been in touch before. So we drove there to introduce ourselves. We wanted to indicate - we are here, we are not far away and we can deliver this and that'.

'It was not a big success. We started getting orders from Sweden now and then'.

'A few years later a large Swedish multinational company approached us through their subsidiary in Norway. They realised that we had the same type of customers, often the same customers, but we served different needs. So they wanted us to be a partner and to serve all their customers'.

Subsequent - Learning from primary international experience:

'First, we learnt a lot from our Swedish customers, about their needs, their expectations... In general we got a better understanding of the Swedish market'.

'While Sweden is so close to us in terms of distance, joint history and culture, only serving our Swedish customers we could realise how different we are. I could not imagine then that we'd ever go to other markets'.

- Sensing IO and entrepreneurial alertness: 'I met this guy here, in the city. Originally he comes from Lithuania, but he had already lived in Norway for more than five years by the time we met. In our small place we do not have a lot of people from Eastern Europe, so it was interesting to talk to him. About different things at first, then about business. He was friendly, trustful and knowledgeable. So, we started thinking about moving a part of our production to Eastern Europe'.

'We talked the same language, and I felt that this could work, it seemed to me that all pieces of the puzzle were well-connected, and I started seeing the whole picture'.

'This guy had many friends in different countries of Eastern Europe, and he knew how things worked in these countries. We visited Lithuania; Latvia and Poland together, but after some
- Acquisition of context-specific knowledge during identification and pursuit of primary IO.

- Subsequent IO were identified via discovery.

- Reliance on local social networks with weak ties in subsequent IO identification.

- Subsequent IO were identified via extension of founder's local social ties. 
Table 6 (continued)

\begin{tabular}{|c|c|c|}
\hline $\begin{array}{l}\text { Case } \\
\text { firm }\end{array}$ & Type of IO & $\begin{array}{l}\text { Key illustrative events } \\
\text { and selected supporting quotes }\end{array}$ \\
\hline
\end{tabular}

considerations, decided that Poland suits more'.

Delta Primary
- Extensive experience in the domestic market:

'When we started the firm, we had already had a working experience as engineers in the same industry, so we knew the industry well, we had some contacts, and we were quite aware about market opportunities in this country, and in this particular region of the country. We worked hard and made every effort to build strong relationships with every customer. Step by step, we became quite known in our business segment'.

'We realised that we were good in developing tailored solutions for our customers. Sometimes it felt impossible to find a solution, but via frequent contacts with our customers we tried to understand better their needs, test our ideas, and, after many iterations, we usually came up with something. Designing a machine requires time and continuous interactions with the customer, whose input is very important'.

'It is not uncommon that we get orders because of recommendations of our customers'.

'It started by coincidence. We did not think about serving foreign customers. We just designed and manufactured machines, different pieces of equipment and tools for various industrial companies in the region. One day we were approached by one intermediary firm wanted to buy a piece of machinery. As we got to know later, we were recommended to this firm by one of our customers, whom we had good and frequent contacts with. It was a good deal for us, and we were very happy to sell this machine. We tried to develop relationships with this intermediary, operated in several industries, including offshore industry, and one day we learnt from them that there were unaddressed needs in this industry, and only in Norway there are numerous prospects, who would be interested in getting a solution. Then we started thinking about focusing on this particular industry and Norwegian
- High needs for product customisation.

- High level of customer involvement in product development/customisation.

- Strong reputation in the domestic market enabled identification of primary IO.

- Strong local business ties are of importance.

- Primary IO was identified via discovery.

- Reliance on local business networks in primary IO identification.

- Primary IO was identified through strengthening of firm's business ties. 
Table 6 (continued)

\begin{tabular}{|c|c|c|c|}
\hline $\begin{array}{l}\text { Case } \\
\text { firm }\end{array}$ & Type of IO & $\begin{array}{l}\text { Key illustrative events } \\
\text { and selected supporting quotes }\end{array}$ & Related findings \\
\hline
\end{tabular}

market. Then, in 2006, we ended up in the international market directly'.

Subsequent - Sensing a foreign market potential for the core product and undertaking deliberate actions (doing extensive marketing research, creating marketing information system, signing an agreement with an exclusive sales agent in Norway, participation in trade shows) in order to identify subsequent IO:

'After five years our international sales generated most of our revenues'.

'We put a lot of time in doing marketing research, we developed a marketing information system mapping and visualising all prospects globally with complete information about specifications of the equipment they use on their drilling platforms. Now we want to understand how we can approach these prospects'.

'Basically, we wanted to have someone who'd take care of processing our new customers. It was the main point to have this sales agent. We have a kind of gentleman's agreement with them. We take care of production and further product development, and they take charge of marketing and sales'.

'We sell to the whole world via Norway, but we can do more...

We can increase our production capacity tenfold; we need another channel to sell even more...'

'We take part in trade shows regularly (three-four times a year), we do extensive market research, we talk with Business Sweden, we try to establish contacts with our prospects, and we try to present ourselves to them. Trade shows seem to be the most important for us, there we have good chances to establish new as well as maintain current relationships with prospects, customers and potential agents'.
- Favourable experience with primary IO is likely to have had an encouraging effect on the firm's ambition to search for subsequent IO.

- International knowledge, acquired in the process of identification and pursuit of primary IO, enabled identification of subsequent IO.

- Subsequent IO were identified via creation.

- Subsequent IO were identified via extension of firm's business ties abroad.

- Reliance on international business networks with weak ties in subsequent IO identification.

Open Access This article is licensed under a Creative Commons Attribution 4.0 International License, which permits use, sharing, adaptation, distribution and reproduction in any medium or format, as long as you give appropriate credit to the original author(s) and the source, provide a link to the Creative Commons licence, and indicate if changes were made. The images or other third party material in this article are included in the article's Creative Commons licence, unless indicated otherwise in a credit line to the material. If material is not 
included in the article's Creative Commons licence and your intended use is not permitted by statutory regulation or exceeds the permitted use, you will need to obtain permission directly from the copyright holder. To view a copy of this licence, visit http://creativecommons.org/licenses/by/4.0/.

\section{References}

Alvarez SA, Barney JB (2007) Discovery and creation: alternative theories of entrepreneurial action. Strateg Entrep J 1(1-2):11-26

Andersson S (2004) Internationalization in different industrial contexts. J Bus Ventur 19(6):851-875

Andersson S, Evers N (2015) International opportunity recognition in international new ventures - a dynamic managerial capabilities perspective. J Int Entrep 13(3):260-276

Andersson U, Blankenburg Holm D, Johanson M (2005) Opportunities, relational embeddedness and network structure. In: Managing opportunity development in business networks. Palgrave Macmillan, London, pp $27-48$

Andersson S, Evers N, Griot C (2013) Local and international networks in small firm internationalization: cases from the Rhône-Alpes medical technology regional cluster. Entrep Reg Dev 25(9-10):867-888

Andersson S, Evers N, Kuivalainen O (2014) International new ventures: rapid internationalization across different industry contexts. Eur Bus Rev 26(5):390-405

Ardichvili A, Cardozo R, Ray S (2003) A theory of entrepreneurial opportunity identification and development. J Bus Ventur 18(1):105-123

Aspelund A, Moen Ø (2005) Small international firms: typology, performance and implications. Manag Int $\operatorname{Rev} 45(3): 37-57$

Bai W, Johanson M (2018) International opportunity networks. Ind Mark Manag 70:167-179

Baron R (2006) Opportunity recognition as pattern recognition: how entrepreneurs "connect the dots" to identify new business opportunities. Acad Manag Perspect 20(1):104-119

Bazeley P, Jackson K (2013) Qualitative data analysis with NVIVO, 2nd edn. Sage, London

Bell J, Crick D, Young S (2004) Small firm internationalization and business strategy: an exploratory study of 'knowledge-intensive' and 'traditional' manufacturing firms in the UK. Int Small Bus J 22(1):23-56

Belso-Martínez JA (2006) Why are some Spanish manufacturing firms internationalizing rapidly? The role of business and institutional international networks. Entrep Reg Dev 18(3):207-226

Bhagavatula S, Elfring T, Tilburg A, van de Bunt G (2010) How social and human capital influence opportunity recognition and resource mobilization in India's handloom industry. J Bus Ventur 25:245260

Blankenburg Holm D, Johanson M, Kao PT (2015) From outsider to insider: opportunity development in foreign market networks. J Int Entrep 13(3):337-359

Buttriss GI, Wilkinson IF (2006) Using narrative sequence methods to advance international entrepreneurship theory. J Int Entrep 4:157-174

Chandra Y, Styles C, Wilkinson I (2009) The recognition of first time international opportunities: evidence from firms in knowledge-based industries. Int Mark Rev 26(1):30-61

Chandra Y, Styles C, Wilkinson I (2012) An opportunity-based view of rapid internationalization. J Int Mark 20(1):74-102

Chandra Y, Styles C, Wilkinson I (2015) Opportunity portfolio: moving beyond single opportunity explanations in international entrepreneurship research. Asia Pac J Manag 32:199-228

Chen G, Gully SM, Eden D (2004) General self-efficacy and self-esteem: toward theoretical and empirical distinction between correlated self-evaluations. J Organ Behav 25(3):375-395

Chetty S, Blankenburg-Holm D (2000) Internationalisation of small to medium-sized manufacturing firms: a network approach. Int Bus Rev 9:77-93

Chetty S, Karami M, Martín Martín O (2018) Opportunity discovery and creation as a duality: evidence from small firms' foreign market entries. J Int Mark 26(3):70-93

Ciravegna L, Majano SB, Zhan G (2014) The inception of internationalization of small and medium enterprises: the role of activeness and networks. J Bus Res 67(6):1081-1089

Coviello NE (2006) The network dynamics of international new ventures. J Int Bus Stud 37(5):713-731

Coviello NE, Jones MV (2004) Methodological issues in international entrepreneurship research. J Bus Ventur 19(4):485-508 
Coviello NE, Munro HJ (1995) Growing the entrepreneurial firm: networking for international market development. Eur J Mark 29(7):49-61

Coviello NE, Munro HJ (1997) Network relationships and the internationalisation process of small software firms. Int Bus Rev 6(4):361-386

Crick D, Spence M (2005) The internationalisation of 'high performing' UK high-tech SMEs: a study of planned and unplanned strategies. Int Bus Rev 14:167-185

Du X, Jiao J, Tseng MM (2006) Understanding customer satisfaction in product customization. Int J Adv Manuf Technol 31:396-406

Eberhard M, Craig J (2013) The evolving role of organisational and personal networks in international market venturing. J World Bus 48:385-397

EC (2003) Commission recommendation of 6 May 2003 concerning the definition of micro, small and medium-sized enterprises (notified under document number C(2003) 1422). Text with EEA relevance 2003/361/EC. Off J Eur Union. http://eurlex.europa.eu/legal-content/EN/TXT/PDF/?uri=CELEX:32003 H0361\&from=EN. Accessed 13 Feb 2020

Eisenhardt KM (1989) Building theories from case study research. Acad Manag Rev 14(4):532-550

Eisenhardt KM, Graebner ME (2007) Theory building from cases: opportunity and challenges. Acad Manag J 50(1):25-32

Elfring T, Hulsink W (2003) Networks in entrepreneurship: the case of high-technology firms. Small Bus Econ 21:409-422

Ellis P (2000) Social ties and foreign market entry. J Int Bus Stud 31(3):443-469

Ellis PD (2011) Social ties and international entrepreneurship: opportunities and constraints affecting firm internationalization. J Int Bus Stud 42(1):99-127

Eriksson K, Majkgård A, Sharma DD (2000) Path dependence and knowledge development in the internationalization process. Manag Int Rev 40(4):307-329

Evers N (2010) Factors influencing the internationalization of new ventures in the Irish aquacultural industry: an exploratory study. J Int Entrep 8(4):392-416

Evers N (2011) International new ventures in "low tech" sectors - a dynamic capabilities perspective. J Small Bus Enterp Dev 18(3):502-528

Evers N, Knight J (2008) Trade shows and small firm internationalisation: a network perspective. Int Mark Rev 25(5):544-562

Evers N, O'Gorman C (2011) Improvised internationalization in new ventures: the role of prior knowledge and networks. Entrep Reg Dev 23(7-8):549-574

Fernhaber S, Li D (2013) International exposure through network relationships: implications for new venture internationalization. J Bus Ventur 28:316-334

Fernhaber S, McDougall P, Oviatt B (2007) Exploring the role of industry structure in new venture internationalization. Entrep Theory Pract 31(4):517-542

Fletcher M, Harris S (2012) Knowledge acquisition for the internationalization of the smaller firm: content and sources. Int Bus Rev 21:631-647

Fombrun CJ (1996) Reputation: realizing value from the corporate image. Harvard Business School Press, Boston

Fombrun CJ, Gardberg NA, Sever JW (2000) The reputation quotient: a multi-stakeholder measure of corporate reputation. J Brand Manag 7:241-255

Francioni B, Vissak T, Musso F (2017) Small Italian wine producers' internationalization: the role of network relationships in the emergence of late starters. Int Bus Rev 26:12-22

Galan N, Torsein E (2018) Crossing the border in a cross-border region: the role of networks in small firms' internationalization. RENT XXXII, Toledo, Spain, 14-16 November. Sustainable entrepreneurship: a win-win strategy for the future, Toledo

Galkina T, Chetty S (2015) Effectuation and networking of internationalizing SMEs. Manag Int Rev 55(5): $647-676$

Goldberg AI, Cohen G, Fiegenbaum A (2003) Reputation building: small business strategies for successful venture development. J Small Bus Manag 41(2):168-186

Granovetter MS (1973) The strength of weak ties. Am J Sociol 78:1360-1380

Granovetter MS (1983) The strength of weak ties: a network theory revisited. Sociol Theory 1(1):201-233

Hennart J-F (2014) The accidental internationalists: a theory of born globals. Entrep Theory Pract 38:117-135

Hilmersson M, Jansson H (2012) International network extension processes to institutionally different markets: entry nodes and processes of exporting SMEs. Int Bus Rev 21(4):682-693

Hilmersson M, Papaioannou S (2015) SME international opportunity scouting - empirical insights on its determinants and outcomes. J Int Entrep 13(3):186-211 
Hirsch-Kreinsen H (2008) Low tech sector: a forgotten sector in innovation policy? J Technol Manag Innov 3(3):11-20

Hohenthal J, Johanson J, Johanson M (2014) Network knowledge and business-relationship value in the foreign market. Int Bus Rev 23:14-19

Hormiga E, García-Almeida DJ (2016) Accumulated knowledge and innovation as antecedents of reputation in new ventures. J Small Bus Enterp Dev 23(2):428-452

Hvam L, Mortensen NH, Riis J (2008) Product customization. Springer, Berlin

Jantunen A, Nummela N, Puumalainen K, Saarenketo S (2008) Strategic orientations of born globals - do they really matter? J World Bus 43(2):158-170

Johanson J, Mattsson L-G (1988) Interorganizational relations in industrial systems: a network approach compared with the transaction-cost approach. Int Stud Manag Organ 18(1):34-48

Johanson J, Vahlne J-E (2006) Commitment and opportunity development in the internationalization process: a note on the Uppsala internationalization process model. Manag Int Rev 46:165-178

Johanson J, Vahlne J-E (2009) The Uppsala internationalization process model revisited: from liability of foreignness to liability of outsidership. J Int Bus Stud 40(9):1411-1431

Jones MV, Coviello N, Tang YK (2011) International entrepreneurship research (1989-2009): a domain ontology and thematic analysis. J Bus Ventur 26:632-659

Kauppinen A, Juho A (2012) Internationalisation of SMEs from the perspective of social learning theory. J Int Entrep 10(3):200-231

Kirzner IM (1997) Entrepreneurial discovery and the competitive market processes: an Austrian approach. J Econ Lit 35(1):60-85

Kontinen T, Ojala A (2011a) Network ties in the international opportunity recognition of family SMEs. Int Bus Rev 20:440-453

Kontinen T, Ojala A (2011b) International opportunity recognition among small and medium-sized family firms. J Small Bus Manag 49(3):490-514

Laperrière A, Spence M (2015) Enacting international opportunities: the role of organizational learning in knowledge-intensive business services. J Int Entrep 13(3):212-241

Laurell H, Andersson S, Achtenhagen L (2013) The importance of industry context for new venture internationalisation: a case study from the life sciences. J Int Entrep 11(4):297-319

Laurell H, Achtenhagen L, Andersson S (2017) The changing role of network ties and critical capabilities in an international new venture's early development. Int Entrep Manag J 13(1):113-140

Leppäaho T, Chetty S, Dimitratos P (2018) Network embeddedness in the internationalization of biotechnology entrepreneurs. Entrep Reg Dev 30(5-6):562-584

Lewis K, Kaufman J, Gonzalez M, Wimmer A, Christakis N (2008) Tastes, ties, and time: a new social network dataset using Facebook. Soc Networks 30(4):330-342

Lööf H, Heshmati A, Asplund R, Nåås S-O (2001) Innovation and performance in manufacturing industries: a comparison of the Nordic countries. Stockholm School of Economics/The Economic Research Institute Working Paper Series in Economics and Finance, 457. http://hdl.handle.net/10419/56168

Lorentz H, Ghauri PN (2010) Demand supply network opportunity development processes in emerging markets: positioning for strategy realization in Russia. Ind Mark Manag 39(2):240-251

Magnani G, Zucchella A (2019) Coping with uncertainty in the internationalisation strategy. Int Mark Rev 36(1):131-163

Mainela T, Puhakka V, Servais P (2014) The concept of international opportunity in international entrepreneurship: a review and a research agenda. Int J Manag Rev 16:105-129

Mainela T, Puhakka V, Sipola S (2018) International entrepreneurship beyond individuals and firms: on the systemic nature of international opportunities. J Bus Ventur 33:534-550

Masiello B, Izzo F (2019) Interpersonal social networks and internationalization of traditional SMEs. J Small Bus Manag 0(0):1-34

Milanov H, Fernhaber SA (2014) When do domestic alliances help ventures abroad? Direct and moderating effects from a learning perspective. J Bus Ventur 29(3):377-391

Miller CC, Cardinal LB, Glick WH (1997) Retrospective reports in organizational research: a reexamination of recent evidence. Acad Manag J 40(1):189-204

Muzychenko O, Liesch PW (2015) International opportunity identification in the internationalisation of the firm. J World Bus 50(4):704-717

Nordman ER, Melén S (2008) The impact of different kinds of knowledge for the internationalization process of born Globals in the biotech business. J World Bus 43(2):171-185

O’Donnell A, Gilmore A, Cummins D, Carson D (2001) The network construct in entrepreneurship research: a review and critique. Manag Decis 39:749-760 
OECD (2011). ISIC (rev. 3) Technology intensity definition: classification of manufacturing industries into categories based on R\&D intensities. OECD Directorate for Science, Technology and Industry, Economic Analysis and Statistics Division, available at https://www.oecd.org/sti/ind/48350231.pdf, accessed October 31, 2018

OECD (2018). Strengthening SMEs and entrepreneurship for productivity and inclusive growth. Key Issues Paper, SME Ministerial conference, Mexico City 22-23 February 2018

Ojala A (2009) Internationalization of knowledge-intensive SMEs: the role of network relationships in the entry to a psychically distant market. Int Bus Rev 18(1):50-59

Oparaocha GO (2015) SMEs and international entrepreneurship: an institutional network perspective. Int Bus Rev 24:861-873

Oviatt BM, McDougall PP (2005) Defining international entrepreneurship and modelling the speed of internationalization. Entrep Theory Pract 29(5):537-553

Oyson MJ, Whittaker H (2015) Entrepreneurial cognition and behaviour in the discovery and creation of international opportunities. J Int Entrep 13:303-336

Patton MQ (2002) Qualitative research and evaluation methods, 3rd edn. Sage, Thousand Oaks, CA

Peiris IK, Akoorie MEM, Sinha P (2012) International entrepreneurship: a critical analysis of studies in the past two decades and future directions for research. J Int Entrep 10:279-324

Perks KJ, Hughes M (2008) Entrepreneurial decision-making in internationalization: propositions from midsize firms. Int Bus Rev 17:310-330

Presutti M, Boari C, Fratocci L (2007) Knowledge acquisition and the foreign development of high-tech startups: a social capital approach. Int Bus Rev 16(1):23-46

Quinton S, Wilson D (2016) Tensions and ties in social media networks: towards a model of understanding business relationship development and business performance enhancement through the use of LinkedIn. Ind Mark Manag 54:15-24

Renko M, Shrader R, Simon M (2012) Perception of entrepreneurial opportunity: a general framework. Manag Decis 50(7):1233-1251

Reuber AR, Fischer E (2005) The company you keep: how young firms in different competitive contexts signal reputation through their customers. Entrep Theory Pract 29:57-78

Reuber AR, Dimitratos P, Kuivalainen O (2017) Beyond categorization: new directions for theory development about entrepreneurial internationalization (editorial). J Int Bus Stud 48:411-422

Reuber AR, Knight GA, Liesch PW, Zhou L (2018) International entrepreneurship: the pursuit of entrepreneurial opportunities across national borders (editorial). J Int Bus Stud 49:395-406

Ripollés-Mélia M, Menguzzato-Boulard M, Sanchez-Peinado L (2007) Entrepreneurial orientation and international commitment. J Int Entrep 5(3-4):65-83

Sarasvathy SD (2001) Causation and effectuation: toward a theoretical shift from economic inevitability to entrepreneurial contingency. Acad Manag Rev 26(2):243-263

Schumpeter, J. A. (1934). The Theory of Economic Development: An Inquiry into Profits, Capital, Credit, Interest, and the Business Cycle (translated by Redvers Opie). Series: Harvard Economic Studies, 46. Cambridge, MA: Harvard University Press

Schweizer R, Johanson J, Vahlne J-E (2010) Internationalization as an entrepreneurial process. J Int Entrep 8(4):343-370

Shane S, Venkataraman S (2000) The promise of entrepreneurship as a field of research. Acad Manag Rev 25(1):217-226

Sharma DD, Blomstermo A (2003) The internationalization process of born globals: a network view. Int Bus Rev 12(6):739-753

Sharma N, Young L, Wilkinson I (2006) The commitment mix: dimensions of commitment in international trading relationships in India. J Int Mark 14:64-91

Sheppard, M. and McNaughton, R. (2012). Born global and born-again global firms: a comparison of internationalization patterns. In M. Gabrielsson and Kirpalani, V. H. M. (Eds.) Handbook of research on born globals, Cheltenham: Edward Elgar, 44-56

Sinkovics RR, Penz E, Ghauri PN (2008) Enhancing the trustworthiness of qualitative research in international business. Manag Int Rev 48(6):689-714

Stake RE (2003) Case studies. In: Denzin NK, Lincoln YS (eds) Strategies of qualitative inquiry. Sage, Thousand Oaks, pp 134-164

Sullivan-Mort G, Weerawardena J (2006) Networking capability and international entrepreneurship: how networks function in Australia born global firms. Int Mark Rev 23(5):549-572

Tolstoy D (2010) Network development and knowledge creation within the foreign market: a study of international entrepreneurial firms. Entrepreneurship and Regional Development 22(5):379-402 
Tracy SJ (2010) Qualitative quality: eight “big-tent” criteria for excellent qualitative research. Qual Inq 16(10): 837-851

Vasilchenko E, Morrish S (2011) The role of entrepreneurial networks in the exploration and exploitation of internationalization opportunities by information and communication technology firms. J Int Mark 19(4): 88-105

Veglio V, Zucchella A (2015) Entrepreneurial firms in traditional industries. Does innovation matter for international growth? J Int Entrep 13(2):138-152

Venkatraman N (1989) Strategic orientation of business enterprises: the construct, dimensionality, and measurement. Manag Sci 35(8):942-962

Welter C, Alvarez S (2015) The state of opportunities: clarifying the transitions between opportunity types. Manag Decis 53(7):1398-1411

Westhead P, Ucbasaran D, Binks M (2004) Internationalization strategies selected by established rural and urban SMEs. J Small Bus Enterp Dev 11:8-22

Yin RK (2014) Case study research design and methods, 5th edn. Sage, Thousand Oaks, CA

Zaefarian R, Eng T-Y, Tasavori M (2016) An exploratory study of international opportunity identification among family firms. Int Bus Rev 25:333-345

Zahra SA (2008) The virtuous cycle of discovery and creation of entrepreneurial opportunities. Strateg Entrep J 2(3):243-257

Zahra SA, Korrib JS, Yu J (2005) Cognition and international entrepreneurship: implications for research on international opportunity recognition and exploitation. Int Bus Rev 14:129-146

Publisher's note Springer Nature remains neutral with regard to jurisdictional claims in published maps and institutional affiliations. 